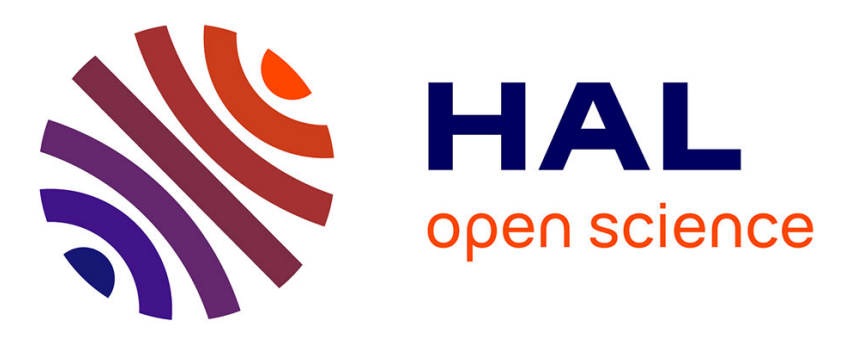

\title{
Directed Studies Towards The Total Synthesis of $(+)$-13-Deoxytedanolide: Simple and Convenient Synthesis of C8-C16 Fragment
}

Sébastien Meiries, Alexandra Bartoli, Mélanie Decostanzi, Jean-Luc Parrain, Laurent Commeiras

\section{To cite this version:}

Sébastien Meiries, Alexandra Bartoli, Mélanie Decostanzi, Jean-Luc Parrain, Laurent Commeiras. Directed Studies Towards The Total Synthesis of (+)-13-Deoxytedanolide: Simple and Convenient Synthesis of C8-C16 Fragment. Organic \& Biomolecular Chemistry, 2013, 11, pp.4882-4890. 10.1039/c3ob40674a . hal-00861650

\section{HAL Id: hal-00861650 https://hal.science/hal-00861650}

Submitted on 16 Sep 2014

HAL is a multi-disciplinary open access archive for the deposit and dissemination of scientific research documents, whether they are published or not. The documents may come from teaching and research institutions in France or abroad, or from public or private research centers.
L'archive ouverte pluridisciplinaire HAL, est destinée au dépôt et à la diffusion de documents scientifiques de niveau recherche, publiés ou non, émanant des établissements d'enseignement et de recherche français ou étrangers, des laboratoires publics ou privés. 


\section{Organic \& \\ Biomolecular Chemistry}

\section{PAPER}

Cite this: Org. Biomol. Chem., 2013, 11, 4882

Received 4th April 2013,

Accepted 21st May 2013

DOI: $10.1039 / c 30 b 40674 a$

www.rsc.org/obc
Directed studies towards the total synthesis of (+)-13-deoxytedanolide: simple and convenient synthesis of the C8-C16 fragment +

\author{
Sébastien Meiries, Alexandra Bartoli, Mélanie Decostanzi, Jean-Luc Parrain* and \\ Laurent Commeiras*
}

A straightforward synthesis of the enantioenriched C8-C16 south part of (+)-13-deoxytedanolide has been reported. The strength of this approach relies on the preparation of similar functionalized fragments via the transformation of a unique dihydrofuran building block through a 1,2-metallate rearrangement.

\section{Introduction}

Tedanolides $^{1}$ and candidaspongiolides ${ }^{2}$ (Fig. 1) are naturally occurring marine macrolides that possess a unique architectural complexity and display remarkable antitumor activity against various cell lines. More precisely, (+)-13-deoxytedanolide 2, which is one of the three members of the tedanolides family, was isolated by Fusetani et al. from the Japanese sea sponge Mycale adhaerens. ${ }^{1 b}$ Interestingly, among all the tedanolide congeners, macrolactone 2 exhibited interesting biological activity against P388 murine leukemia cells ${ }^{3}$ with an $\mathrm{IC}_{50}=$ $94 \mathrm{pg} \mathrm{mol}^{-1}$. Its cytotoxicity is thought to be related to the inhibition of protein synthesis by competing with deacylated $t$ RNAs for E site (located in the eukaryotic ribosome) binding. ${ }^{4}$ It is worth noting that it is the first example of a macrolide to inhibit the eukaryotic ribosome.

The unique architecture and biological properties of tedanolides have triggered considerable synthetic efforts ${ }^{5}$ and still constitute a significant and attractive synthetic challenge, given the numerous labile aldol units, the fragile trisubstituted $\alpha$-hydroxy-epoxide, the disubstituted $(Z$ )-double bond and the trisubstituted $(E)$-olefin encased in an 18-membered macrolide framework, punctuated with up to 13 stereogenic centers.

Herein, to address this challenge, we described a straightforward and highly convergent strategy for the stereocontrolled synthesis of C8-C16 fragment 6 of (+)-13-deoxytedanolide 2 (Scheme 1). Our convergent and simple approach is based on

Aix Marseille Université, CNRS, iSm2 UMR 7313, 13397 Marseille, France. E-mail: jl.parrain@univ-amu.fr, laurent.commeiras@univ-amu.fr; Fax: +334912891 87; Tel: +33491288914, +33491288926 $\dagger$ Electronic supplementary information (ESI) available: Synthesis procedures, ${ }^{1} \mathrm{H}$ and ${ }^{13} \mathrm{C}$ NMR spectra for all compounds. See DOI: $10.1039 / \mathrm{c} 3 \mathrm{ob} 40674 \mathrm{a}$

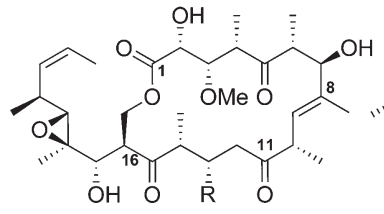

$\mathrm{R}=\mathrm{OH}:(+)$-tedanolide (1)

$\mathrm{R}=\mathrm{H}:(+)$-13-deoxytedanolide (2)

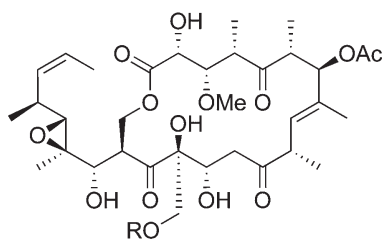

Candidaspongiolide (4) $\mathrm{R}=\mathrm{H}$, or different acyl moieties
Fig. 1 Structures of tedanolides and candidaspongiolides.

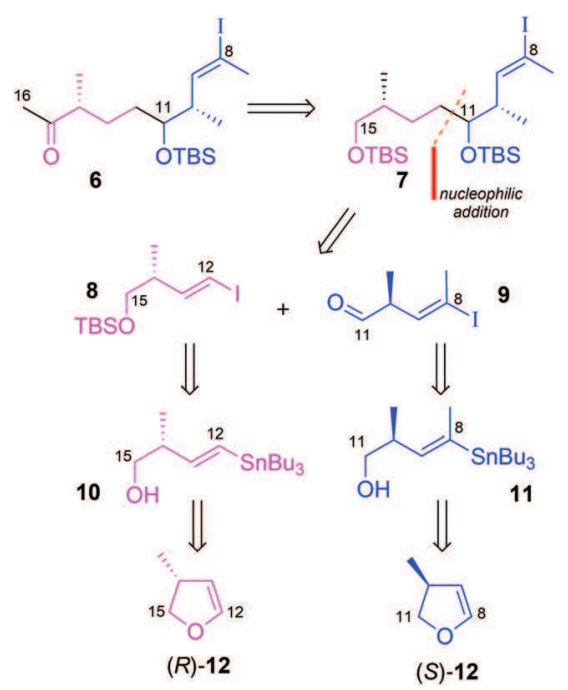

Scheme 1 Retrosynthesis analysis. 
the preparation of two equally-functionalized homoallylic alcohols 10 and 11, which could be readily prepared from a similar 1,2-metallate rearrangement using both enantiomers of the 3-methyl-2,3-dihydrofuran 12. The assembly of these two fragments via a nucleophilic addition followed by further transformations should provide the C8-C16 fragment of 2 .

\section{Results and discussion}

The synthesis of homoallylic alcohols $\mathbf{1 0}$ and $\mathbf{1 1}$ requires the preparation of the optically pure $(R)$ - and $(S)-3$-methyl-2,3dihydrofurans 12 (Scheme 2). After an overview of the methods developed by the groups of Ardisson ${ }^{6}$ and Jamisson, ${ }^{7}$ Evan's oxazolidinone procedure appeared to be the best synthetic path for the preparation of $(S)-\mathbf{1 2}$ and $(R)-\mathbf{1 2}$ and the further installment of the stereogenic centers in C10 and C14.

Starting from the known (S)-propionyl oxazolidinone $(S)-\mathbf{1 3},{ }^{8}$ the diastereoselective alkylation (performed on a $>20 \mathrm{~g}$ scale) using allyl iodide furnished the desired oxazolidinone $(S)-14$ in good yield $(82 \%)$ and in excellent $\mathrm{dr}(>20: 1){ }^{9}$ Removal of the chiral auxiliary was performed with lithium borohydride to give, in $\mathbf{7 3 \%}$ yield, the volatile alkenol $(R)-\mathbf{1 5}$ and the recovered oxazolinone which was successfully reused in the sequence. ${ }^{9,10}$ Ozonolysis followed by triphenylphosphine $\left(\mathrm{PPh}_{3}\right)$ reductive treatment reliably provided the lactol $(R)-16$ (56\%) which was ultimately dehydrated under acidic conditions to yield the (R)-3-methyl-2,3-dihydrofuran $(R)-\mathbf{1 2}$, in a multi-gram scale $(85 \%))^{6,11}$ The same process was also employed to access the opposite $(S)$-enantiomer of the dihydrofuran 12, starting this time from $(R)$-propionyl oxazolidinone $(R)-\mathbf{1 3}$. Dihydrofurans $(R)-\mathbf{1 2}$ and $(S)-\mathbf{1 2}$ were prepared over 4 steps in $29 \%$ and $38 \%$ yields from $(S)-\mathbf{1 3}$ and $(R)-\mathbf{1 3}$ respectively. With the two dihydrofuran enantiomers 12 in hand, we proceeded to perform the 1,2-cuprate rearrangement ${ }^{12}$ to access homoallylic alcohols 10 and 11. This one-step process employing the pre-made Lipshutz reagent allows the preparation of di- or tri-substituted functionalized double bonds via a dyotropic rearrangement. The intermediate vinylcuprates generated with total control of the diastereoselectivity can be quenched with various electrophiles to afford diversely substituted double bonds. In the presence of $\mathrm{Bu}\left(\mathrm{Bu}_{3} \mathrm{Sn}\right) \mathrm{CuLi}, \quad$ LiCN, 2-lithio-4-methyl-4,5-dihydrofuran enantiomers undergo this dyotropic rearrangement to give the corresponding vinyl cuprates. Hydrolysis $\left(\mathrm{NH}_{4} \mathrm{Cl}-\mathrm{NH}_{4} \mathrm{OH}\right)$ or alkylation (MeI trapping) of these last intermediates furnished the desired functionalized homoallylic alcohols $10(99 \%)$ and $11(76 \%)$ respectively with total control of the $(E)$-geometry of the double bond.

Before coupling homoallylic alcohols together, several classic organic transformations were necessary (Scheme 3). First of all, vinyl stannane $\mathbf{1 0}$ was turned into the corresponding vinyl iodide $\mathbf{1 7}$ with total retention of the configuration of the double bond, by simple treatment of $\mathbf{1 0}$ with a solution of iodine in diethyl ether $(91 \%){ }^{13,14}$ The primary alcohol 17 was then protected as TBS silyl ether 8, in 94\% yield, to furnish the first functionalized fragment. It must be noted that the iododestannylation reaction and the TBS protection steps can be successfully inverted without a significant effect on the overall yield. In parallel, the alcohol $\mathbf{1 1}$ was transformed into the corresponding vinyl iodide 18 (98\% yield) and the latter was smoothly oxidised with Dess-Martin periodinane without any detectable epimerization at $\mathrm{C} 10 .{ }^{15}$ Although the obtained aldehyde 9 was successfully purified by flash column chromatography for characterization, it proved to be sensitive to extensive manipulations. Therefore it was usually taken on crude to the next synthetic step.

The assembly of fragments 9 (C8-C11) and 8 (C12-C15) was then accomplished via a nucleophilic addition reaction. The iodine-lithium exchange of $\mathbf{8}$ proceeded rapidly and cleanly at $-100{ }^{\circ} \mathrm{C}$ and the resulting intermediate vinyllithium 19 was added to aldehyde 9 to furnish the desired alcohol 20 in a $3: 1$ diastereoisomeric ratio in $71 \%$ yield. These conditions for this temperamental addition step were crucial for optimal and reproducible results. Whereas the addition of molecular sieves or the order of addition was quite negligible, the freshness of the unstable aldehyde $\mathbf{9}$ appeared to be crucial for the success of the coupling. The reaction was found to be extremely fast at

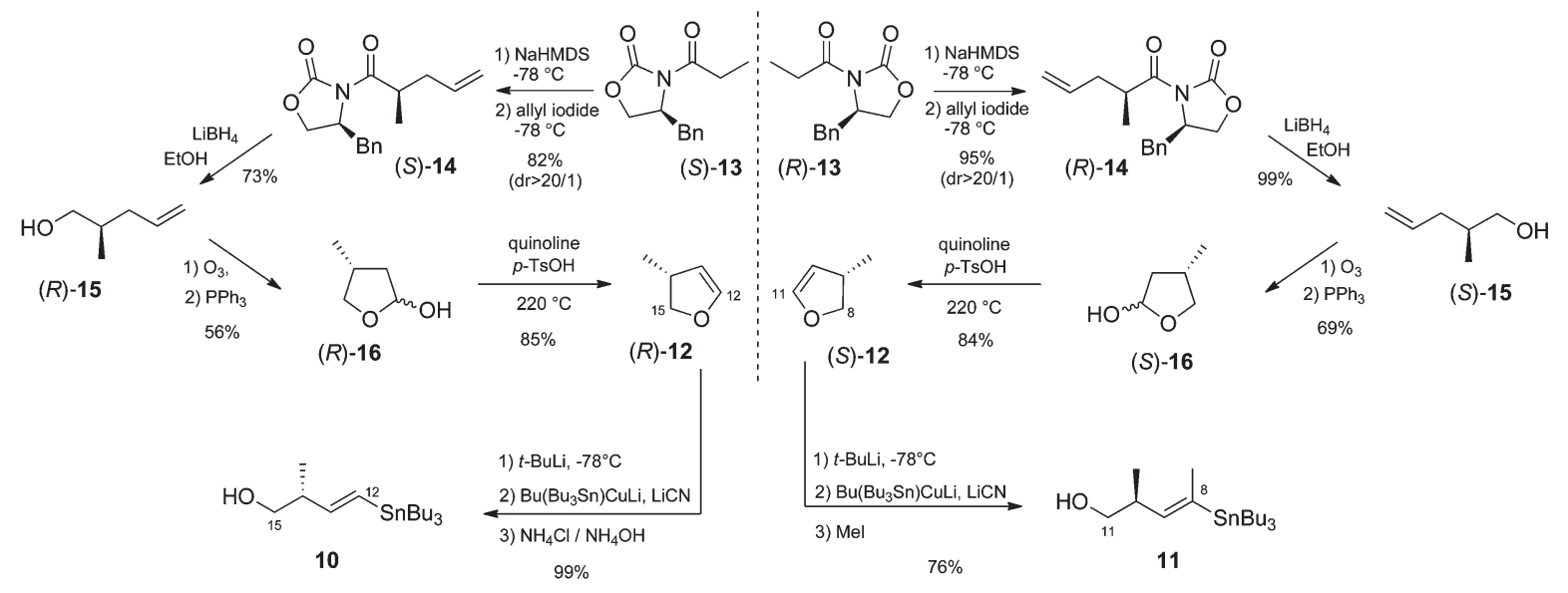

Scheme 2 Synthesis of enantiopure dihydrofurans and functionalized homoallylic alcohol. 

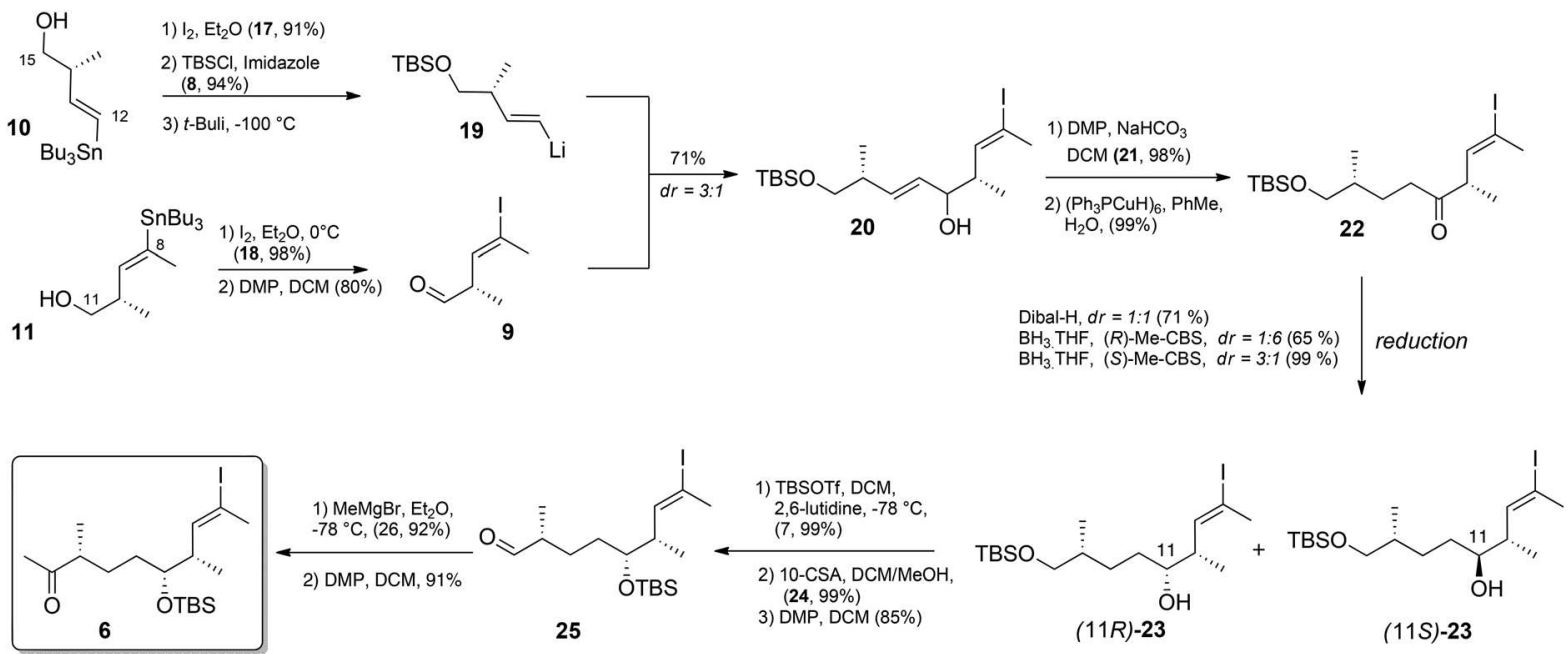

Scheme 3 Synthesis of a C8-C16 fragment.

$-100{ }^{\circ} \mathrm{C}$ but was generally warmed up to $-78{ }^{\circ} \mathrm{C}$ for $1 \mathrm{~h}$ to secure full conversion. The alcohol 20 was then smoothly oxidized to the corresponding enone $\mathbf{2 1}$ with buffered DessMartin periodinane in excellent yield (98\%) with no epimerisation. The resulting $\alpha, \beta$-unsaturated ketone 21 was then reduced to the corresponding ketone $\mathbf{2 2}$ with commercially available Stryker's reagent in $99 \%$ yield. Alternatively, double bond reduction to 20 using Crabtree or Wilkinson's catalysts under $\mathrm{H}_{2}$ proved to be unsuccessful. At this stage, a large number of conditions were used to protect ketones $\mathbf{2 1}$ and $\mathbf{2 2}$ as acetals, dithianes or hydrazones. However, all our attempts were unsuccessful as both ketones appeared to be surprisingly unreactive under usual methods and decomposed under more drastic conditions. Alternatively, ketone 22 was reduced with Dibal-H in good yield (71\%) giving the desired alcohol 23 as a separable 1:1 diastereoisomeric mixture. Our initial strategy was to carry on the synthesis with the $1: 1$ diastereoisomeric mixture and ultimately oxidise the C11-alcohol to the corresponding desired ketone present in tedanolides. However, for a better clarity of characterization data, the reduction was further optimised using diastereoselective Corey-BakshiShibata's reduction. ${ }^{16}$

$(R)$ - and $(S)$-Me-CBS reagents provided a 1:6 and 3:1 ratio of diastereoisomers in $65 \%$ and $99 \%$ yield respectively. According to Corey-Bakshi-Shibata's reduction model, we can assume that reduction reaction performed with the $(R)$-Me-CBS reagent would furnish mostly (11S)-23 while (11R)-23 would be obtained using $(S)$-Me-CBS. At the end of the synthesis, vinyl iodide $(11 R)-23$ was turned quantitatively into the corresponding bisTBS protected analogue 7. The primary TBS ether group of 7 was then selectively cleaved under mild acidic conditions to provide the primary alcohol $\mathbf{2 4}$ (99\% yield). The latter was further oxidized (85\%) and the aldehyde 25 was reacted with methylmagnesium bromide to furnish the secondary alcohol 26 $(92 \%)$ as a $1: 1.5$ mixture of two diastereomers. Finally, a subsequent DMP oxidation afforded the desired C8-C16 fragment 6 as a single isomer in $91 \%$ yield over two steps.

\section{Conclusions}

In summary, we have accomplished an enantioselective synthesis of $\mathrm{C} 8-\mathrm{C} 16$ fragment $\mathbf{6}$ of (+)-13-deoxytedanolide 2 . The synthesis featured the preparation of two equally-functionalized homoallylic alcohols via a 1,2-metallate rearrangement using both enantiomers of the 3-methyl-2,3-dihydrofuran 12 . This simple and convergent strategy should allow the synthesis of analogues of the tedanolide family.

\section{Experimental section}

\section{General procedure}

All reagents were obtained from commercial sources and used as supplied unless otherwise stated. Anhydrous THF, $\mathrm{Et}_{2} \mathrm{O}$, toluene and $\mathrm{CH}_{2} \mathrm{Cl}_{2}$ were obtained from an MBraun ${ }^{\circledR}$ SPS-800 solvent purification system. Light petroleum refers to the fraction of petrol ether that was distilled between $40^{\circ} \mathrm{C}$ and $65^{\circ} \mathrm{C}$. The reaction mixtures were magnetically stirred and monitored by TLC, which were performed on Merck® 60F254 plates and achieved under $254 \mathrm{~nm}$ UV light, visualized with an aqueous solution of potassium permanganate or an ethanolic solution of molybdophosphoric acid, followed by treatment with a heat gun. Flash chromatography was performed with Merck® Kieselgel 60 (230-400) mesh silica gel. NMR data were recorded on Bruker Avance 300 and 400 spectrometers in $\mathrm{C}_{6} \mathrm{D}_{6}$ or $\mathrm{CDCl}_{3}$ and chemical shifts $(\delta)$ were given in ppm relative to the residual non-deuterated solvent signal for ${ }^{1} \mathrm{H}$ NMR $\left(\mathrm{C}_{6} \mathrm{D}_{6}\right.$ : $7.16 \mathrm{ppm})\left(\mathrm{CDCl}_{3}: 7.26 \mathrm{ppm}\right)$ and relative to the deuterated solvent signal for ${ }^{13} \mathrm{C}$ NMR $\left(\mathrm{C}_{6} \mathrm{D}_{6}: 128.06 \mathrm{ppm}\right)\left(\mathrm{CDCl}_{3}\right.$ : $77.16 \mathrm{ppm}$ ); coupling constants $(J)$ are in Hertz, and the classical abbreviations are used to describe the signal multiplicity ( $\mathrm{s}=$ singlet, $\mathrm{d}=$ doublet, $\mathrm{t}=$ triplet, sept $=$ septet, $\mathrm{m}=$ multi plet, $\mathrm{dd}=$ doublet of doublets, $\mathrm{dt}=$ doublets of triplets, $\mathrm{br}=$ broad, etc.). NMR spectra were assigned using information ascertained from DEPT, COSY and HMQC experiments. 
Compound 14. ${ }^{9}$ To a stirred solution of oxazolidinone $(S)-13$ $(20.05 \mathrm{~g}, 86 \mathrm{mmol})$ in THF $(240 \mathrm{~mL})$ was added dropwise NaHMDS (1.0 M in THF, $90 \mathrm{~mL}, 90 \mathrm{mmol})$ at $-78^{\circ} \mathrm{C}$. The reaction mixture was allowed to stir for $1 \mathrm{~h}$ at $-78{ }^{\circ} \mathrm{C}$, then allyl iodide $(11.8 \mathrm{~mL}, 129 \mathrm{mmol})$ was added. The mixture was stirred at $-78^{\circ} \mathrm{C}$ for $3 \mathrm{~h}$ (until complete disappearance of starting material), then quenched at $-78{ }^{\circ} \mathrm{C}$ with an aqueous saturated $\mathrm{NH}_{4} \mathrm{Cl}$ solution. The aqueous layer was extracted with $\mathrm{Et}_{2} \mathrm{O}$ and the combined organic layers were dried over anhydrous $\mathrm{MgSO}_{4}$ and concentrated under vacuum. The residue was purified by flash silica gel chromatography (light petroleum- $\left.\mathrm{Et}_{2} \mathrm{O}, 8: 2\right)$ to give $(S)-\mathbf{1 4}(18.42 \mathrm{~g}, 82 \%$ yield).

$(R)-14$ (5.19 g, 95\% yield) was obtained using the same procedure starting from $(R)-\mathbf{1 4}(4.88 \mathrm{~g}, 21 \mathrm{mmol})$.

$(S)-\mathbf{1 4}[\alpha]_{\mathrm{D}}^{19}=+38.0\left(c 1, \mathrm{CHCl}_{3}\right) ;(R)-\mathbf{1 4}[\alpha]_{\mathrm{D}}^{19}=-39.0(c 1$, $\left.\mathrm{CHCl}_{3}\right) ;{ }^{1} \mathrm{H}$ NMR $\left(300 \mathrm{MHz}, \mathrm{CDCl}_{3}\right) \delta 1.18(3 \mathrm{H}, \mathrm{d}, J=6.8 \mathrm{~Hz}$, $\left.\mathrm{CH}_{3}\right), 2.19-2.28\left(1 \mathrm{H}, \mathrm{m}, \mathrm{CH}_{2}\right), 2.48-2.57\left(1 \mathrm{H}, \mathrm{m}, \mathrm{CH}_{2}\right), 2.69$ $\left(1 \mathrm{H}, \mathrm{dd}, J=13.4\right.$ and $\left.9.8 \mathrm{~Hz}, \mathrm{CH}_{2}\right), 3.27(1 \mathrm{H}, \mathrm{dd}, J=13.4$ and $\left.3.2 \mathrm{~Hz}, \mathrm{CH}_{2}\right), 3.36(1 \mathrm{H}, \mathrm{m}, J=6.8 \mathrm{~Hz}, \mathrm{CH}), 4.11-4.21(2 \mathrm{H}, \mathrm{m}$, $\left.\mathrm{CH}_{2}\right), 4.64-4.71(1 \mathrm{H}, \mathrm{m}, \mathrm{CH}), 5.04-5.13\left(2 \mathrm{H}, \mathrm{m}, \mathrm{CH}_{2}\right), 5.76-5.89$ $(\mathrm{m}, 1 \mathrm{H}, \mathrm{CH}), 7.20-7.35\left(5 \mathrm{H}, \mathrm{m}, \mathrm{CH}_{\mathrm{Ar}}\right) ;{ }^{13} \mathrm{C} \mathrm{NMR}\left(\mathrm{CDCl}_{3}\right.$, $75 \mathrm{MHz}) \delta 16.5\left(\mathrm{CH}_{3}\right), 37.2(\mathrm{CH}), 38.0\left(\mathrm{CH}_{2}\right), 38.1\left(\mathrm{CH}_{2}\right), 55.4$ (CH), $66.1\left(\mathrm{CH}_{2}\right), 117.3\left(\mathrm{CH}_{2}\right), 127.4\left(\mathrm{CH}_{\mathrm{Ar}}\right), 129.0\left(2 \times \mathrm{CH}_{\mathrm{Ar}}\right)$, $129.5\left(2 \times \mathrm{CH}_{\mathrm{Ar}}\right), 135.4(\mathrm{CH}), 135.5\left(\mathrm{C}_{\mathrm{Ar}}\right), 153.2(\mathrm{C}), 176.6(\mathrm{C})$.

Compound 15. ${ }^{9,10}$ To a stirred solution of $(S)-14$ (39.5 g, $114 \mathrm{mmol})$ in $\mathrm{Et}_{2} \mathrm{O}(900 \mathrm{~mL})$ was added at $0{ }^{\circ} \mathrm{C}$ absolute $\mathrm{EtOH}$ (10.1 mL, $173 \mathrm{mmol})$, followed by $\mathrm{LiBH}_{4}(4 \mathrm{M}$ in THF, $43.3 \mathrm{~mL}$, $173 \mathrm{mmol}$ ). The reaction mixture was allowed to warm up to room temperature overnight, then was quenched with an aqueous solution of $\mathrm{NaOH}(1 \mathrm{M}, 880 \mathrm{~mL})$ and was stirred until both layers became clear. The aqueous layer was extracted with $\mathrm{Et}_{2} \mathrm{O}$ and the combined organic layers were washed with a saturated aqueous $\mathrm{NaCl}$ solution, dried over anhydrous $\mathrm{MgSO}_{4}$ and concentrated under vacuum. The residue was purified by flash silica gel chromatography (light petroleum-EtOAc, $1: 1$ ) to give $(R)-\mathbf{1 5}$ (10.56 g, 73\% yield) and the recovered starting oxazolidinone (18.66 g, 73\%).

$(S)-\mathbf{1 5}(10.46 \mathrm{~g}, 99 \%$ yield $)$ was obtained using the same procedure starting from $(R)-\mathbf{1 4}(28.56 \mathrm{~g}, 104 \mathrm{mmol})$.

$(R)-15[\alpha]_{\mathrm{D}}^{19}=+4.3\left(c \quad 1, \mathrm{CHCl}_{3}\right) ;(S)-\mathbf{1 5}[\alpha]_{\mathrm{D}}^{24}=-2.6(c) 1$, $\left.\mathrm{CHCl}_{3}\right) ;{ }^{1} \mathrm{H}$ NMR $\left(200 \mathrm{MHz}, \mathrm{CDCl}_{3}\right) \delta 0.92(3 \mathrm{H}, \mathrm{d}, J=6.7 \mathrm{~Hz}$, $\left.\mathrm{CH}_{3}\right), 1.37(1 \mathrm{H}, \mathrm{br} \mathrm{s}, \mathrm{OH}), 1.65-1.82(1 \mathrm{H}, \mathrm{m}, \mathrm{CH}), 1.87-2.01$ $\left(1 \mathrm{H}, \mathrm{m}, \mathrm{CH}_{2}\right), 2.11-2.25\left(1 \mathrm{H}, \mathrm{m}, \mathrm{CH}_{2}\right), 3.40-3.55\left(2 \mathrm{H}, \mathrm{m}, \mathrm{CH}_{2}\right)$, 4.99-5.09 $\left(2 \mathrm{H}, \mathrm{m}, \mathrm{CH}_{2}\right), 5.71-5.92(\mathrm{~m}, 1 \mathrm{H}, \mathrm{CH}),{ }^{13} \mathrm{C}$ NMR $\left(50 \mathrm{MHz}, \mathrm{CDCl}_{3}\right) \delta 16.4\left(\mathrm{CH}_{3}\right), 35.6(\mathrm{CH}), 37.9\left(\mathrm{CH}_{2}\right), 67.7$ $\left(\mathrm{CH}_{2}\right), 116.1\left(\mathrm{CH}_{2}\right), 137.1(\mathrm{CH})$.

Compound 12. ${ }^{6,11}$ Toa stirred solution of $(R)-15(7.51 \mathrm{~g}$, $75 \mathrm{mmol})$ in dichloromethane $(150 \mathrm{~mL})$, at $-78{ }^{\circ} \mathrm{C}$, was bubbled ozone until completion as indicated by the disappearance of the characteristic color of sudan red III. The reaction mixture was then purged with argon and quenched with $\mathrm{PPh}_{3}$ $(21.6 \mathrm{~g}, 82 \mathrm{mmol})$. The mixture was allowed to warm up to room temperature and was stirred overnight before being concentrated under vacuum. The residue was purified by distillation under reduced pressure $\left(T_{65.8} \mathrm{mbar}=80^{\circ} \mathrm{C}\right)$ to give $(R)-\mathbf{1 6}$ $(4.32 \mathrm{~g}, 56 \%$ yield). A solution of the above $(R)-16$ (4.32,
$42 \mathrm{mmol}$ ), PTSA (16 mg, $0.084 \mathrm{mmol}$ ) and quinoline $(2.27 \mathrm{~mL})$ was heated from 160 to $245{ }^{\circ} \mathrm{C}$. The distillated furan (bp = $80-90{ }^{\circ} \mathrm{C}$ ) was separated from water and filtered through a pad of anhydrous $\mathrm{Na}_{2} \mathrm{SO}_{4}$ to give, after further purification by distillation $\left(T_{760 \mathrm{mmHg}}=72{ }^{\circ} \mathrm{C}\right)$ over $\mathrm{CaH}_{2},(R)-\mathbf{1 2}(3.04 \mathrm{~g}, 85 \%)$.

$(S)-12$ (3.72 g, 59\% yield over two steps) was obtained using the same procedure starting from $(S)-\mathbf{1 5}(7.55 \mathrm{~g}, 75 \mathrm{mmol})$.

${ }^{1} \mathrm{H}$ NMR $\left(400 \mathrm{MHz}, \mathrm{CDCl}_{3}\right) \delta 1.07\left(3 \mathrm{H}, \mathrm{d}, J=6.8 \mathrm{~Hz}, \mathrm{CH}_{3}\right)$, 2.98-3.07 (1H, m, CH), $3.85\left(1 \mathrm{H}, \mathrm{dd}, J=8.8\right.$ and $\left.6.8 \mathrm{~Hz}, \mathrm{CH}_{2}\right)$, $4.37\left(1 \mathrm{H}, \mathrm{dd}, J=9.8\right.$ and $\left.8.8 \mathrm{~Hz}, \mathrm{CH}_{2}\right), 4.93(1 \mathrm{H}, \mathrm{t}, J=2.5 \mathrm{~Hz}$, $\mathrm{CH}), 6.29(1 \mathrm{H}, \mathrm{t}, J=2.5 \mathrm{~Hz}, \mathrm{CH}) ;{ }^{13} \mathrm{C}$ NMR $\left(50 \mathrm{MHz}, \mathrm{CDCl}_{3}\right)$ $\delta 20.6\left(\mathrm{CH}_{3}\right), 36.5(\mathrm{CH}), 76.7\left(\mathrm{CH}_{2}\right), 106.3(\mathrm{CH}), 145.2(\mathrm{CH})$.

Compound 10. A solution of dihydrofuran $(R)-\mathbf{1 2}(720 \mathrm{mg}$, $8.56 \mathrm{mmol})$ in anhydrous THF $(8.8 \mathrm{~mL})$ was cooled down to $-60{ }^{\circ} \mathrm{C}$ and subjected to slow addition of $t$-BuLi $(1.6 \mathrm{M}$ in pentane, $6.94 \mathrm{~mL}, 11.1 \mathrm{mmol})$. After $10 \mathrm{~min}$ at $-60{ }^{\circ} \mathrm{C}$, the reaction mixture was stirred at $0{ }^{\circ} \mathrm{C}$ for $50 \mathrm{~min}$. In a different flask, a solution of CuCN $(1.53 \mathrm{~g}, 17.1 \mathrm{mmol})$ in anhydrous THF $(49 \mathrm{~mL})$ was prepared and cooled down to $-78{ }^{\circ} \mathrm{C}$ before being subjected to the slow addition of $n$-BuLi $(2.5 \mathrm{M}$ in hexanes, $13.7 \mathrm{~mL}, 34.2 \mathrm{mmol}$ ). The mixture was allowed to warm up to $-60{ }^{\circ} \mathrm{C}$, causing the $\mathrm{CuCN}$ to solubilize and forming a clear yellow solution. The reaction mixture was recooled to $-78{ }^{\circ} \mathrm{C}$ and $n-\mathrm{Bu}_{3} \mathrm{SnH}(9.07 \mathrm{~mL}, 34.2 \mathrm{mmol})$ was slowly added to it, resulting in a slight change of colour. The orange mixture was then stirred at $-78{ }^{\circ} \mathrm{C}$ for 15 min until no more hydrogen was released. The first solution was rapidly cannulated to the Lipshutz' reagent solution at $-78^{\circ} \mathrm{C}$ and the resulting mixture was then placed in an ice bath. After $2 \mathrm{~h}$ at $0{ }^{\circ} \mathrm{C}$, the reaction mixture was quenched by addition of a $4: 1$ solution of saturated $\mathrm{NH}_{4} \mathrm{Cl}$ and $30 \% \mathrm{NH}_{4} \mathrm{OH}(11 \mathrm{~mL})$. A saturated solution of brine was added and the phases were separated. The aqueous layer was extracted with diethyl ether and the organic fractions were combined and dried over anhydrous $\mathrm{Na}_{2} \mathrm{SO}_{4}$. The solvents were evaporated under reduced pressure to afford a crude oil, which was purified by flash column chromatography (light petroleum- $\mathrm{Et}_{2} \mathrm{O}, 1 / 99$ to $8 / 2$ ). The pure vinyl stannane 10 (3.2 g, 99\%) was obtained as a clear and col-

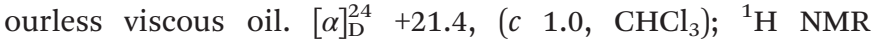
$\left(400 \mathrm{MHz}, \mathrm{CDCl}_{3}\right) \delta 0.84-0.90\left(15 \mathrm{H}, \mathrm{m}, 3 \times \mathrm{CH}_{3}\right.$ and $\left.3 \times \mathrm{CH}_{2}\right)$, $1.02\left(3 \mathrm{H}, \mathrm{d}, J=6.8 \mathrm{~Hz}, \mathrm{CH}_{3}\right), 1.24-1.53\left(12 \mathrm{H}, \mathrm{m}, 6 \times \mathrm{CH}_{2}\right)$, 2.34-2.44 (1H, m, CH), 3.38-3.44 (1H, m, $\left.\mathrm{CH}_{2}\right), 3.47-3.53(1 \mathrm{H}$, $\left.\mathrm{m}, \mathrm{CH}_{2}\right), 5.79\left(1 \mathrm{H}, \mathrm{dd}, J=19.0\right.$ and $\left.7.0 \mathrm{~Hz},{ }^{3} J_{\mathrm{Sn}-\mathrm{H}}=70 \mathrm{~Hz}, \mathrm{CH}\right)$, $5.99\left(1 \mathrm{H}\right.$, br d, $\left.J=19.0 \mathrm{~Hz},{ }^{2} J_{\mathrm{Sn}-\mathrm{H}}=18 \mathrm{~Hz}, \mathrm{CH}\right) ;{ }^{13} \mathrm{C} \mathrm{NMR}$ $\left(75 \mathrm{MHz}, \mathrm{CDCl}_{3}\right) \delta 9.5\left(3 \times \mathrm{CH}_{2},{ }^{1} J_{\mathrm{Sn}-\mathrm{C}}=334 \mathrm{~Hz}\right), 13.4(3 \times$ $\left.\mathrm{CH}_{3}\right), 16.1\left(\mathrm{CH}_{3}\right), 27.3\left(3 \times \mathrm{CH}_{2},{ }^{3} J_{\mathrm{Sn}-\mathrm{C}}=54 \mathrm{~Hz}\right), 29.2\left(3 \times \mathrm{CH}_{2}\right.$, $\left.{ }^{2} J_{\mathrm{Sn}-\mathrm{C}}=21 \mathrm{~Hz}\right), 44.5\left(\mathrm{CH},{ }^{3} J_{\mathrm{Sn}-\mathrm{C}}=57 \mathrm{~Hz}\right), 66.9\left(\mathrm{CH}_{2}\right), 129.5(\mathrm{C} 3$, $\left.\mathrm{CH},{ }^{2} J_{\mathrm{Sn}-\mathrm{C}}=23 \mathrm{~Hz}\right), 151.2(\mathrm{CH}) ; \mathrm{IR}$ (thin film) $\nu_{\max }=3325$, 2956, 2923, 2871, 2852, 1597, 1455, 1376, 1072, 1031, $990 \mathrm{~cm}^{-1}$; LRMS $\mathrm{m} / z$ (ESI) $399(\mathrm{M}+\mathrm{Na})^{+}$; HRMS $\mathrm{m} / z$ (ESI) calcd for $\mathrm{C}_{17} \mathrm{H}_{37} \mathrm{OSn}[\mathrm{M}+\mathrm{H}]^{+}:$377.1860, found 377.1861.

Compound 11. A solution of dihydrofuran $(S)-\mathbf{1 2}(840 \mathrm{mg}$, $9.99 \mathrm{mmol})$ in anhydrous THF $(10.3 \mathrm{~mL})$ was cooled down to $-60{ }^{\circ} \mathrm{C}$ and subjected to the slow addition of $t$-BuLi $(1.6 \mathrm{M}$ in pentane, $8.08 \mathrm{~mL}, 12.9 \mathrm{mmol})$. After $10 \mathrm{~min}$ at $-60{ }^{\circ} \mathrm{C}$, the reaction mixture was stirred at $0{ }^{\circ} \mathrm{C}$ for $50 \mathrm{~min}$. In a different 
flask, a solution of $\mathrm{CuCN}(1.78 \mathrm{~g}, 19.9 \mathrm{mmol})$ in anhydrous THF $(57.0 \mathrm{~mL})$ was prepared and cooled down to $-78{ }^{\circ} \mathrm{C}$ before being subjected to the slow addition of $n$-BuLi $(2.5 \mathrm{M}$ in hexanes, $16.0 \mathrm{~mL}, 40.0 \mathrm{mmol}$ ). The mixture was allowed to warm up to $-60{ }^{\circ} \mathrm{C}$, causing the $\mathrm{CuCN}$ to solubilize and forming a clear yellow solution. The reaction mixture was recooled to $-78{ }^{\circ} \mathrm{C}$ and $n-\mathrm{Bu}_{3} \mathrm{SnH}(10.6 \mathrm{~mL}, 39.4 \mathrm{mmol})$ was slowly added to it, resulting in a slight change of colour. The orange mixture was then stirred at $-78^{\circ} \mathrm{C}$ for $15 \mathrm{~min}$ until no more hydrogen was released. The first solution was rapidly cannulated to the Lipshutz' reagent solution at $-78^{\circ} \mathrm{C}$ and the resulting mixture was then placed in an ice bath. After $2 \mathrm{~h}$ at $0{ }^{\circ} \mathrm{C}$, the reaction mixture was recooled to $-30{ }^{\circ} \mathrm{C}$ before being treated with iodomethane $(6.2 \mathrm{~mL}, 0.1 \mathrm{~mol})$ passed through a plug of basic alumina. The reaction mixture was allowed to warm up to room temperature and was stirred for $3 \mathrm{~h}$ before being quenched by addition of a $4: 1$ solution of saturated $\mathrm{NH}_{4} \mathrm{Cl}$ and $30 \% \mathrm{NH}_{4} \mathrm{OH}(13 \mathrm{~mL})$. A saturated solution of brine was added and the phases were separated. The aqueous layer was extracted with diethyl ether and the organic fractions were combined and dried over anhydrous $\mathrm{Na}_{2} \mathrm{SO}_{4}$. The solvents were evaporated under reduced pressure to afford a crude oil, which was purified by flash column chromatography (light petroleum- $\mathrm{Et}_{2} \mathrm{O}, 1 / 99$ to $8 / 2$ ). The pure vinyl stannane 11 (2.94 g, $76 \%$ ) was obtained as a yellow to colourless clear viscous oil. $[\alpha]_{\mathrm{D}}^{21}-31.8$ (c 1.0, $\left.\mathrm{CHCl}_{3}\right) ;{ }^{1} \mathrm{H} \mathrm{NMR}\left(400 \mathrm{MHz}, \mathrm{CDCl}_{3}\right)$ $\delta$ 0.84-0.98 (18H, $4 \times \mathrm{CH}_{3}$ and $\left.3 \times \mathrm{CH}_{2}\right), 1.16-1.56(12 \mathrm{H}, \mathrm{m}$, $\left.6 \times \mathrm{CH}_{2}\right), 1.88\left(3 \mathrm{H}, \mathrm{d}, J=1.9 \mathrm{~Hz},{ }^{3} J_{\mathrm{Sn}-\mathrm{H}}=44 \mathrm{~Hz}, \mathrm{CH}_{3}\right)$, 2.77-2.99 (1H, m, CH), 3.30-3.36 (1H, m, CH $\left.\mathrm{H}_{2}\right), 3.43-3.50(1 \mathrm{H}$, $\left.\mathrm{m}, \mathrm{CH}_{2}\right), 5.23\left(1 \mathrm{H}, \mathrm{dq}, J=9.0\right.$ and $\left.1.9 \mathrm{~Hz},{ }^{3} J_{\mathrm{Sn}-\mathrm{H}}=70 \mathrm{~Hz}, \mathrm{CH}\right)$; ${ }^{13} \mathrm{C} \mathrm{NMR}\left(75 \mathrm{MHz}, \mathrm{CDCl}_{3}\right) \delta 9.3\left(3 \times \mathrm{CH}_{2},{ }^{1} J_{\mathrm{Sn}-\mathrm{C}}=322 \mathrm{~Hz}\right), 13.8$ $\left(3 \times \mathrm{CH}_{3}\right), 16.9\left(\mathrm{CH}_{3}\right), 19.7\left(\mathrm{CH}_{3}\right), 27.5\left(\mathrm{C} 9,3 \times \mathrm{CH}_{2},{ }^{3} J_{\mathrm{Sn}-\mathrm{C}}=54\right.$ $\mathrm{Hz}), 29.3\left(3 \times \mathrm{CH}_{2},{ }^{2} J_{\mathrm{Sn}-\mathrm{C}}=20 \mathrm{~Hz}\right), 35.3\left(\mathrm{CH}_{3},{ }^{3} J_{\mathrm{Sn}-\mathrm{C}}=53 \mathrm{~Hz}\right)$, $67.7\left(\mathrm{CH}_{2}\right), 141.2(\mathrm{C}), 143.1\left(\mathrm{CH},{ }^{2} J_{\mathrm{Sn}-\mathrm{C}}=24 \mathrm{~Hz}\right)$; IR (thin film) $\nu_{\max }=3330,2955,2924,2871,2850,1456,1377,1071,1030$, $970 \mathrm{~cm}^{-1}$; HRMS (ESI) $m / z$ calcd for $\mathrm{C}_{18} \mathrm{H}_{39} \mathrm{OSn}[\mathrm{M}+\mathrm{H}]^{+}$: 391.2017, found 391.2017.

Compound 17. ${ }^{14}$ A solution of vinyl stannane 10 (3.44 g, $9.17 \mathrm{mmol})$ in anhydrous diethyl ether $(40 \mathrm{~mL})$ was treated with a premade solution of iodine $(2.70 \mathrm{~g}, 10.6 \mathrm{mmol})$ in dry diethyl ether $(40 \mathrm{~mL})$ at $0{ }^{\circ} \mathrm{C}$. After $2 \mathrm{~h}$ at room temperature, the dark brown reaction mixture was quenched by addition of an aqueous solution of potassium fluoride $(1.0 \mathrm{M}, 20 \mathrm{~mL})$ and acetone $(20 \mathrm{~mL})$ and was stirred for $1 \mathrm{~h}$. The resulting suspension was then filtered through Celite ${ }^{\circledR}$ and flushed with ethyl acetate. The organics were washed with a saturated solution of $\mathrm{Na}_{2} \mathrm{~S}_{2} \mathrm{O}_{3}(3 \times 50 \mathrm{~mL})$ and were dried over anhydrous $\mathrm{MgSO}_{4}$. Concentration under reduced pressure afforded a crude yellow oil which was purified by flash column chromatography (light petroleum- $\mathrm{Et}_{2} \mathrm{O}, 7 / 3$ to $1 / 1$ ) to yield the pure vinyl iodide 17 $(1.75 \mathrm{~g}, 91 \%)$ as a yellowish to colourless viscous oil. $[\alpha]_{\mathrm{D}}^{25}+23.1,\left(c 1.0, \mathrm{CHCl}_{3}\right) ;{ }^{1} \mathrm{H}$ NMR $\left(300 \mathrm{MHz}, \mathrm{CDCl}_{3}\right) \delta 1.00(3 \mathrm{H}$, $\left.\mathrm{d}, J=6.8 \mathrm{~Hz}, \mathrm{CH}_{3}\right), 1.88-1.92(1 \mathrm{H}, \mathrm{m}, \mathrm{OH}), 2.33-2.46(1 \mathrm{H}, \mathrm{m}$, $\mathrm{CH}), 3.40-3.53\left(2 \mathrm{H}, \mathrm{m}, \mathrm{CH}_{2}\right), 6.12(1 \mathrm{H}, \mathrm{d}, J=14.5 \mathrm{~Hz}, \mathrm{CH}), 6.45$ $(1 \mathrm{H}, \mathrm{dd}, J=14.5$ and $7.9 \mathrm{~Hz}, \mathrm{CH}) ;{ }^{13} \mathrm{C} \mathrm{NMR} \mathrm{(75} \mathrm{MHz}, \mathrm{CDCl}_{3}$ ) $\delta 15.6\left(\mathrm{CH}_{3}\right), 43.4(\mathrm{CH}), 66.5\left(\mathrm{CH}_{2}\right), 76.2(\mathrm{CH}), 148.6(\mathrm{CH})$.
Compound 8. A solution of alcohol 17 (1.55 g, $7.31 \mathrm{mmol})$ in anhydrous dichloromethane $(27 \mathrm{~mL})$ was treated with tertbutyldimethylsilyl chloride (775 mg, $10.28 \mathrm{mmol}$ ) and imidazole $(0.775 \mathrm{~g}, 11.38 \mathrm{mmol})$ at room temperature. The reaction mixture was stirred overnight before being transferred to a separating funnel and washed with water. The organic fraction was dried over anhydrous $\mathrm{Na}_{2} \mathrm{SO}_{4}$, filtered and concentrated under reduced pressure to give a clear and colourless crude oil. Purification by flash column chromatography (light petroleum- $\mathrm{Et}_{2} \mathrm{O}, 1 / 0$ to $9 / 1$ ) afforded the pure vinyl iodide 8 $(2.23 \mathrm{~g}, 94 \%)$ as a clear colourless oil. $[\alpha]_{\mathrm{D}}^{25}+20.8,(c) 1.0$, $\left.\mathrm{CHCl}_{3}\right) ;{ }^{1} \mathrm{H}$ NMR $\left(400 \mathrm{MHz}, \mathrm{CDCl}_{3}\right) \delta 0.05\left(6 \mathrm{H}, \mathrm{s}, 2 \times \mathrm{CH}_{3}\right), 0.90$ $\left(9 \mathrm{H}, \mathrm{s}, 3 \times \mathrm{CH}_{3}\right), 1.01\left(3 \mathrm{H}, \mathrm{d}, J=6.8 \mathrm{~Hz}, \mathrm{CH}_{3}\right), 2.33-2.40(1 \mathrm{H}$, $\mathrm{m}, \mathrm{CH}), 3.45\left(1 \mathrm{H}, \mathrm{dd}, J=9.8\right.$ and $\left.6.4 \mathrm{~Hz}, \mathrm{CH}_{2}\right), 3.48(1 \mathrm{H}, \mathrm{dd}, J=$ 9.8 and $\left.6.4 \mathrm{~Hz}, \mathrm{CH}_{2}\right), 6.06(1 \mathrm{H}$, br dd, $J=14.6 \mathrm{~Hz}, \mathrm{CH}), 6.49$ $(1 \mathrm{H}, \mathrm{dd}, J=14.6$ and $6.5 \mathrm{~Hz}, \mathrm{CH}) ;{ }^{13} \mathrm{C} \mathrm{NMR}\left(100 \mathrm{MHz}, \mathrm{CDCl}_{3}\right)$ $\delta-5.2\left(2 \times \mathrm{CH}_{3}\right), 15.7\left(\mathrm{CH}_{3}\right), 18.4(\mathrm{C}), 26.0\left(3 \times \mathrm{CH}_{3}\right), 43.3(\mathrm{CH})$, $67.0\left(\mathrm{CH}_{2}\right), 75.2(\mathrm{CH}), 149.2(\mathrm{CH})$; IR (thin film) $\nu_{\max }=2955$, 2928, 2856, 1605, 1471, 1386, 1361, 1252, 1187, 1088, 1024, 1006, $947 \mathrm{~cm}^{-1}$; LRMS m/z (ESI) $349(\mathrm{M}+\mathrm{Na})^{+}$; HRMS $\mathrm{m} / \mathrm{z}$ (ESI) calcd for $\mathrm{C}_{11} \mathrm{H}_{24} \mathrm{OSiI}[\mathrm{M}+\mathrm{H}]^{+}$: 327.0636, found 327.0640 .

Compound 18. A solution of vinyl stannane 11 (2.70 g, $6.94 \mathrm{mmol})$ in anhydrous diethyl ether $(40 \mathrm{~mL})$ was treated with a premade solution of iodine $(2.10 \mathrm{~g}, 8.27 \mathrm{mmol})$ in dry diethyl ether $(40 \mathrm{~mL})$ at $0{ }^{\circ} \mathrm{C}$. After $2 \mathrm{~h}$ at room temperature, the dark brown reaction mixture was quenched by addition of an aqueous solution of potassium fluoride $(1.0 \mathrm{M}, 16 \mathrm{~mL})$ and acetone $(16 \mathrm{~mL})$ and was stirred for $1 \mathrm{~h}$. The resulting suspension was then filtered through Celite ${ }^{\circledR}$ and flushed with ethyl acetate. The organics were washed with a saturated solution of $\mathrm{Na}_{2} \mathrm{~S}_{2} \mathrm{O}_{3}$ and were dried over anhydrous $\mathrm{MgSO}_{4}$. Concentration under reduced pressure afforded a crude yellow oil which was purified by flash column chromatography (light petroleum$\mathrm{Et}_{2} \mathrm{O}, 7 / 3$ to $\left.1 / 1\right)$ to yield the pure vinyl iodide $18(1.54 \mathrm{~g}, 98 \%)$ as a yellowish to colourless viscous oil. $[\alpha]_{\mathrm{D}}^{25}-31.3,(c$ 1.0, $\left.\mathrm{CHCl}_{3}\right) ;{ }^{1} \mathrm{H} \mathrm{NMR}\left(400 \mathrm{MHz}, \mathrm{CDCl}_{3}\right) \delta 0.95(3 \mathrm{H}, \mathrm{d}, J=6.8 \mathrm{~Hz}$, $\left.\mathrm{CH}_{3}\right), 1.82-1.85(1 \mathrm{H}, \mathrm{m}, \mathrm{OH}), 2.41\left(3 \mathrm{H}, \mathrm{d}, J=1.5 \mathrm{~Hz}, \mathrm{CH}_{3}\right)$, 2.57-2.68 (1H, m, CH), 3.36-3.51 (2H, m, CH $\left.\mathrm{CH}_{2}\right), 5.96(1 \mathrm{H}, \mathrm{br}$ $\mathrm{dq}, J=9.8,1.5 \mathrm{~Hz}, \mathrm{CH}) ;{ }^{13} \mathrm{C} \mathrm{NMR}\left(100 \mathrm{MHz}, \mathrm{CDCl}_{3}\right) \delta 16.4$ $\left(\mathrm{CH}_{3}\right), 28.2\left(\mathrm{CH}_{3}\right), 38.6(\mathrm{CH}), 67.0\left(\mathrm{CH}_{2}\right), 95.6(\mathrm{CH}), 143.6(\mathrm{CH})$; IR (thin film) $\nu_{\max }=3332,2958,2926,2870,1635,1429,1377$, 1217, 1119, 1076, 1030, 996, $\mathrm{cm}^{-1}$; LRMS m/z (ESI) $249(\mathrm{M}+$ $\mathrm{Na})^{+}$; HRMS $m / z$ (ESI) calcd for $\mathrm{C}_{6} \mathrm{H}_{15} \mathrm{NOI}\left[\mathrm{M}+\mathrm{NH}_{4}\right]^{+}$: 244.0193, found 244.0185.

Compound 9. A solution of alcohol 11 (1.54 g, $6.81 \mathrm{mmol})$ in dichloromethane $(55 \mathrm{~mL})$ was cooled down to $0{ }^{\circ} \mathrm{C}$ and treated with Dess-Martin periodinane (1.06 g, $2.50 \mathrm{mmol}$ ). The pink-red reaction mixture was allowed to warm up slowly (kept slightly below $20^{\circ} \mathrm{C}$ ) and was treated with additional Dess-Martin periodinane $(2 \times 1.06 \mathrm{~g}, 2 \times 2.50 \mathrm{mmol}$, added in 2 portions every $30 \mathrm{~min}$ ). The reaction mixture was quenched at $0{ }^{\circ} \mathrm{C}$ by addition of a $1: 1$ mixture of saturated aqueous solutions of $\mathrm{Na}_{2} \mathrm{~S}_{2} \mathrm{O}_{3}$ and $\mathrm{NaHCO}_{3}(40 \mathrm{~mL})$. The biphasic mixture was stirred at $0{ }^{\circ} \mathrm{C}$ until both phases become clear and was then transferred to a separating funnel containing diethyl ether. The phases were separated and the organic layer was 
washed with the $\mathrm{Na}_{2} \mathrm{~S}_{2} \mathrm{O}_{3}-\mathrm{NaHCO}_{3}$, then with water. The organic fraction was subsequently dried over anhydrous $\mathrm{Na}_{2} \mathrm{SO}_{4}$, filtered and concentrated under reduced pressure at room temperature. The resulting smelly colourless crude oil was then rapidly taken on crude to the next reaction as it was proved to degrade fairly quickly as it turns pink/brown. A sample was further purified (80\%) by flash chromatography (light petroleum- $\mathrm{Et}_{2} \mathrm{O}, 7 / 3$ ) for analytical analysis. ${ }^{1} \mathrm{H}$ NMR $\left(400 \mathrm{MHz}, \mathrm{CDCl}_{3}\right) \delta 1.21\left(3 \mathrm{H}, \mathrm{d}, J=7.0 \mathrm{~Hz}, \mathrm{CH}_{3}\right), 2.46(3 \mathrm{H}, \mathrm{d}$, $\left.J=1.5 \mathrm{~Hz}, \mathrm{CH}_{3}\right), 3.23-3.31(1 \mathrm{H}, \mathrm{m}, \mathrm{CH}), 6.06(1 \mathrm{H}, \mathrm{br} \mathrm{dq}, J=$ 9.3, $1.5 \mathrm{~Hz}, \mathrm{CH}), 9.51(1 \mathrm{H}, \mathrm{d}, J=1.7 \mathrm{~Hz}, \mathrm{CH}) ;{ }^{13} \mathrm{C} \mathrm{NMR}$ $\left(100 \mathrm{MHz}, \mathrm{CDCl}_{3}\right) \delta 13.8\left(\mathrm{CH}_{3}\right), 28.4\left(\mathrm{CH}_{3}\right), 48.8(\mathrm{CH}), 98.1$ $(\mathrm{CH}), 136.6(\mathrm{CH}), 199.3(\mathrm{CHO})$.

Compound 20. A solution of iodide $8(1.85 \mathrm{~g}, 5.67 \mathrm{mmol})$ in anhydrous diethyl ether $(40 \mathrm{~mL})$ containing a small piece of $\mathrm{CaH}_{2}$ was treated with $n$-BuLi $(2.5 \mathrm{M}$ in hexanes, $2.30 \mathrm{~mL}$, $5.75 \mathrm{mmol})$ at $-100{ }^{\circ} \mathrm{C}$. The reaction mixture was allowed to warm up to $-78{ }^{\circ} \mathrm{C}$ and was stirred for $30 \mathrm{~min}$ before being recooled to $-100{ }^{\circ} \mathrm{C}$. The previous solution was then quickly cannulated to a $-100{ }^{\circ} \mathrm{C}$ premade solution of crude aldehyde 9 $(1.52 \mathrm{~g}, 6.8 \mathrm{mmol})$ in dry diethyl ether $(25 \mathrm{~mL})$ containing a small piece of $\mathrm{CaH}_{2}$. The reaction mixture was allowed to warm up slowly at $-78{ }^{\circ} \mathrm{C}$ and was stirred for 15 min before being quenched by addition of a saturated solution of $\mathrm{NH}_{4} \mathrm{Cl}$ $(15 \mathrm{~mL})$ (caution: water reacts violently with $\left.\mathrm{CaH}_{2} ! ! !\right)$. The cold bath was removed straight away and the biphasic mixture was stirred for $15 \mathrm{~min}$ to be then placed in a separating funnel. The phases were separated and the ether layer was washed with water. The organics were dried over anhydrous $\mathrm{Na}_{2} \mathrm{SO}_{4}$ and subsequently filtered. Concentration under reduced pressure afforded an unclear yellow oil $(3.85 \mathrm{~g})$ which was purified by flash column chromatography (light petroleum- $\mathrm{Et}_{2} \mathrm{O}$, $8 / 2$ to $0 / 1)$ to yield the pure allylic alcohol $20(1.72 \mathrm{~g}, 71 \%)$ as a $3: 1$ inseparable mixture of diastereoisomers. Major diastereoisomer only: ${ }^{1} \mathrm{H}$ NMR $\left(400 \mathrm{MHz}, \mathrm{CDCl}_{3}\right) \delta 0.05\left(6 \mathrm{H}, \mathrm{s}, 2 \times \mathrm{CH}_{3}\right)$, $0.89\left(1 \mathrm{H}, \mathrm{s}, 3 \times \mathrm{CH}_{3}\right), 1.00\left(6 \mathrm{H}, \mathrm{d}, J=6.8 \mathrm{~Hz}, 2 \times \mathrm{CH}_{3}\right), 1.66$ $(1 \mathrm{H}$, br s, OH $), 2.29-2.36(1 \mathrm{H}, \mathrm{m}, \mathrm{CH}), 2.39(3 \mathrm{H}, \mathrm{d}, J=1.5 \mathrm{~Hz}$, $\left.\mathrm{CH}_{3}\right), 2.50-2.59(1 \mathrm{H}, \mathrm{m}, \mathrm{CH}), 3.40(1 \mathrm{H}, \mathrm{dd}, J=9.8$ and $6.8 \mathrm{~Hz}$, $\left.\mathrm{CH}_{2}\right), 3.49\left(1 \mathrm{H}, \mathrm{dd}, J=9.8\right.$ and $\left.6.3 \mathrm{~Hz}, \mathrm{CH}_{2}\right), 3.88(1 \mathrm{H}$, app br t, $J=6.5 \mathrm{~Hz}, \mathrm{CH}), 5.45(1 \mathrm{H}, \mathrm{br} \mathrm{dd}, J=15.6$ and $6.8 \mathrm{~Hz}, \mathrm{CH}), 5.60$ $(1 \mathrm{H}, \mathrm{br} \mathrm{dd}, J=15.6$ and $6.3 \mathrm{~Hz}, \mathrm{CH}), 5.99(1 \mathrm{H}, \mathrm{br} \mathrm{dq}, J=9.8$ and $1.5 \mathrm{~Hz}, \mathrm{CH}) ;{ }^{13} \mathrm{C}$ NMR $\left(100 \mathrm{MHz}, \mathrm{CDCl}_{3}\right) \delta-5.3\left(2 \times \mathrm{CH}_{3}\right)$, $15.9\left(\mathrm{CH}_{3}\right), 16.5\left(\mathrm{CH}_{3}\right), 18.3(\mathrm{C}), 25.9\left(3 \times \mathrm{CH}_{3}\right), 28.1\left(\mathrm{CH}_{3}\right), 39.0$ (CH), $41.7(\mathrm{CH}), 67.9\left(\mathrm{CH}_{2}\right), 76.3(\mathrm{CH}), 94.6(\mathrm{CI}), 129.8(\mathrm{CH})$, $135.8(\mathrm{CH}), 142.9(\mathrm{CH})$; IR (thin film) $\nu_{\max }=3419,2958,2930$, 2858, 1638, 1473, 1388, 1257, 1089, 1009, $974 \mathrm{~cm}^{-1}$; LRMS m/z (ESI) $447(\mathrm{M}+\mathrm{Na})^{+}$; HRMS $m / z$ (ESI) calcd for $\mathrm{C}_{17} \mathrm{H}_{37} \mathrm{NO}_{2} \mathrm{SiI}$ $\left[\mathrm{M}+\mathrm{NH}_{4}\right]^{+}:$442.1633, found 442.1633.

Compound 21. A solution of alcohol $20(50 \mathrm{mg}, 0.12 \mathrm{mmol})$ in dichloromethane $(2.5 \mathrm{~mL})$ was cooled down to $0{ }^{\circ} \mathrm{C}$ and treated with solid $\mathrm{NaHCO}_{3}(12 \mathrm{mg}, 0.142 \mathrm{mmol})$ and DessMartin periodinane $(60 \mathrm{mg}, 0.142 \mathrm{mmol})$. The reaction mixture was allowed to warm up slowly to room temperature and was stirred for $1 \mathrm{~h}$ until completion as indicated by TLC analysis. The reaction mixture was quenched at $0{ }^{\circ} \mathrm{C}$ by addition of a 1:1 mixture of saturated aqueous solutions of
$\mathrm{Na}_{2} \mathrm{~S}_{2} \mathrm{O}_{3}$ and $\mathrm{NaHCO}_{3}(6 \mathrm{~mL})$. The biphasic mixture was stirred at $0{ }^{\circ} \mathrm{C}$ until both phases become clear and was then transferred to a separating funnel containing diethyl ether. The phases were separated and the organic layer was washed with saturated aqueous solutions of $\mathrm{Na}_{2} \mathrm{~S}_{2} \mathrm{O}_{3}, \mathrm{NaHCO}_{3}$, then with water. The organic fraction was subsequently dried over anhydrous $\mathrm{Na}_{2} \mathrm{SO}_{4}$, filtered and concentrated under reduced pressure at room temperature. The resulting unclear yellowish crude oil was then purified by flash column chromatography (light petroleum- $\mathrm{Et}_{2} \mathrm{O}, 8 / 2$ ) to yield the pure enone 21 (49 mg, $98 \%)$ as a clear colourless viscous oil. $[\alpha]_{\mathrm{D}}^{21}+52.5\left(c 1.0, \mathrm{CHCl}_{3}\right)$; ${ }^{1} \mathrm{H}$ NMR $\left(400 \mathrm{MHz}, \mathrm{C}_{6} \mathrm{D}_{6}\right) \delta 0.00\left(6 \mathrm{H}, \mathrm{s}, 2 \times \mathrm{CH}_{3}\right), 0.82(3 \mathrm{H}, \mathrm{d}$, $\left.J=6.8 \mathrm{~Hz}, \mathrm{CH}_{3}\right), 0.94\left(9 \mathrm{H}, \mathrm{s}, 3 \times \mathrm{CH}_{3}\right), 0.99(3 \mathrm{H}, \mathrm{d}, J=7.0 \mathrm{~Hz}$, $\left.\mathrm{CH}_{3}\right), 2.12\left(3 \mathrm{H}\right.$, br d, $\left.J=1.5 \mathrm{~Hz}, \mathrm{CH}_{3}\right), 2.22(1 \mathrm{H}$, app sept, $J=$ $6.3 \mathrm{~Hz}, \mathrm{CH}), 3.19(1 \mathrm{H}, \mathrm{dq}, J=9.8$ and $7.0 \mathrm{~Hz}, \mathrm{CH}), 3.28(2 \mathrm{H}, \mathrm{d}$, $\left.J=6.0 \mathrm{~Hz}, \mathrm{CH}_{2}\right), 6.06(1 \mathrm{H}$, br dd, $J=15.8$ and $1.3 \mathrm{~Hz}, \mathrm{CH}), 6.25$ $(1 \mathrm{H}, \mathrm{br} \mathrm{dq}, J=9.8$ and $1.5 \mathrm{~Hz}, \mathrm{CH}), 6.90(1 \mathrm{H}, \mathrm{dd}, J=15.8$ and $7.3 \mathrm{~Hz}, \mathrm{CH}) ;{ }^{13} \mathrm{C}$ NMR $\left(100 \mathrm{MHz}, \mathrm{C}_{6} \mathrm{D}_{6}\right) \delta-5.3\left(2 \times \mathrm{CH}_{3}\right), 15.7$ $\left(\mathrm{CH}_{3}\right), 16.3\left(\mathrm{CH}_{3}\right), 18.5(\mathrm{C}), 26.1\left(3 \times \mathrm{CH}_{3}\right), 27.9\left(\mathrm{CH}_{3}\right), 39.6$ $(\mathrm{CH}), 47.2(\mathrm{CH}), 67.1\left(\mathrm{CH}_{2}\right), 96.1(\mathrm{C}), 127.5(\mathrm{CH}), 140.3(\mathrm{CH})$, 149.8 (CH), 196.9 (C); IR (thin film) $\nu_{\max }=2955,2927,2854$, 1697, 1673, 1626, 1471, 1459, 1253, 1189, 1129, 1097, 1084, 1029, $980 \mathrm{~cm}^{-1}$; LRMS $\mathrm{m} / z$ (ESI) $445(\mathrm{M}+\mathrm{Na})^{+}$; HRMS $\mathrm{m} / \mathrm{z}$ (ESI) calcd for $\mathrm{C}_{17} \mathrm{H}_{32} \mathrm{O}_{2} \mathrm{SiI}[\mathrm{M}+\mathrm{H}]^{+}$: 423.1211, found 423.1211.

Compound 22. A solution of enone $21(776 \mathrm{mg}, 1.84 \mathrm{mmol})$ in anhydrous toluene $(44 \mathrm{~mL})$ and water $(107 \mu \mathrm{L}, 5 \mu \mathrm{mol})$ was degassed in bubbling argon for $20 \mathrm{~min}$ at room temperature. Fresh hexa(triphenylphosphine copper hydride) (950 mg, $0.48 \mathrm{mmol}, 2.9$ eq. of hydride) was quickly poured into the reaction mixture which was stirred until completion ( $15 \mathrm{~min})$ as indicated by TLC analysis. The solution was directly loaded onto silica and was purified by flash column chromatography (100\% light petroleum) with no prior workup. Concentration under reduced pressure afforded the crude ketone 22 as a yellow oil containing triphenylphosphine oxide as the main impurity. Triphenylphosphine oxide crystallized out from the neat oil when exposed to the air and was removed by addition of light petroleum and subsequent filtration. Evaporation of the solvents gave the pure ketone $22(775 \mathrm{mg}, 99 \%)$ as a clear colourless oil. $[\alpha]_{\mathrm{D}}^{22}+65.6,\left(c\right.$ 1.0, $\left.\mathrm{CHCl}_{3}\right) ;{ }^{1} \mathrm{H}$ NMR $(400 \mathrm{MHz}$, $\left.\mathrm{CDCl}_{3}\right) \delta 0.05\left(6 \mathrm{H}, \mathrm{s}, 2 \times \mathrm{CH}_{3}\right), 0.87\left(3 \mathrm{H}, \mathrm{d}, J=6.6 \mathrm{~Hz}, \mathrm{CH}_{3}\right)$, $0.90\left(9 \mathrm{H}, \mathrm{s}, 3 \times \mathrm{CH}_{3}\right), 1.16\left(3 \mathrm{H}, \mathrm{d}, J=6.8 \mathrm{~Hz}, \mathrm{CH}_{3}\right), 1.30-1.43$ $\left(1 \mathrm{H}, \mathrm{m}, \mathrm{CH}_{2}\right), 1.51-1.62(1 \mathrm{H}, \mathrm{m}, \mathrm{CH}), 1.62-1.73\left(1 \mathrm{H}, \mathrm{m}, \mathrm{CH}_{2}\right)$, $2.36-2.55\left(2 \mathrm{H}, \mathrm{m}, \mathrm{CH}_{2}\right), 2.46\left(3 \mathrm{H}, \mathrm{d}, J=1.5 \mathrm{~Hz}, \mathrm{CH}_{3}\right), 3.33-3.40$ $(1 \mathrm{H}, \mathrm{m}, \mathrm{CH}), 3.42\left(2 \mathrm{H}, \mathrm{d}, J=5.9 \mathrm{~Hz}, \mathrm{CH}_{2}\right), 6.12(1 \mathrm{H}, \mathrm{dq}, J=$ 10.0 and $1.5 \mathrm{~Hz}, \mathrm{CH}) ;{ }^{13} \mathrm{C}$ NMR $\left(100 \mathrm{MHz}, \mathrm{CDCl}_{3}\right) \delta-5.2(2 \times$ $\left.\mathrm{CH}_{3}\right), 16.3\left(\mathrm{CH}_{3}\right), 16.8\left(\mathrm{CH}_{3}\right), 18.5(\mathrm{C}), 26.1\left(3 \times \mathrm{CH}_{3}\right), 27.4$ $\left(\mathrm{CH}_{2}\right), 28.1\left(\mathrm{CH}_{3}\right), 35.4(\mathrm{CH}), 38.8\left(\mathrm{CH}_{2}\right), 48.7(\mathrm{CH}), 68.2\left(\mathrm{CH}_{2}\right)$, 96.1 (C), 139.9 (CH), 209.9 (C); IR (thin film) $\nu_{\max }=2955,2929$, 2883, 2856, 1716, 1472, 1462, 1434, 1252, 1117, 1091, 1037, 1028, $1005 \mathrm{~cm}^{-1}$; LRMS $\mathrm{m} / \mathrm{z}$ (ESI) $447(\mathrm{M}+\mathrm{Na})^{+}$; HRMS $\mathrm{m} / \mathrm{z}$ (ESI) calcd for $\mathrm{C}_{17} \mathrm{H}_{34} \mathrm{O}_{2} \mathrm{SiI}[\mathrm{M}+\mathrm{H}]^{+}$: 425.1367, found 425.1367.

Compound 23. Procedure A: A solution of ketone 22 $(775 \mathrm{mg}, 1.83 \mathrm{mmol})$ in anhydrous diethyl ether $(15 \mathrm{~mL})$ was 
treated with a solution of Dibal-H $(1.0 \mathrm{M}$ in hexanes, $3.51 \mathrm{~mL}$, $3.51 \mathrm{mmol}$ ) at $-78{ }^{\circ} \mathrm{C}$. After $10 \mathrm{~min}$ at $-78{ }^{\circ} \mathrm{C}$, the reaction mixture was quenched by addition of ethyl acetate $(5 \mathrm{~mL})$, then with a saturated solution of $\mathrm{NaHCO}_{3}(10 \mathrm{~mL})$. After stirring the biphasic mixture for $15 \mathrm{~min}$ at room temperature, the phases were separated and the ether layer was filtered through a short pad of Celite ${ }^{\circledR}$. Concentration under reduced pressure provided a clear and colourless crude oil containing a $1: 1$ mixture of diastereoisomers $(S)$-23 and $(R)$-23. Several purifications by flash column chromatography (light petroleum$\mathrm{Et}_{2} \mathrm{O}, 9 / 1$ to $8 / 2$ ) enable the complete separation of both diastereoisomers (238 mg, 31\%) and (313 mg, 40\%) as clear and colourless oils.

Procedure B: To a stirred solution of ketone 22 (10 $\mathrm{mg}$, $0.023 \mathrm{mmol})$ in THF $(0.6 \mathrm{~mL})$ was added at $-55{ }^{\circ} \mathrm{C}(S)$-CBS (1.0 $\mathrm{M}$ in THF, $45 \mu \mathrm{L}, 0.045 \mathrm{mmol}$ ) followed by $\mathrm{BH}_{3}$. THF $(1 \mathrm{M}$ in THF, $45 \mu \mathrm{L}, 0.045 \mathrm{mmol})$. The solution was stirred at $-55^{\circ} \mathrm{C}$ until completion $(20 \mathrm{~min}$ ) and allowed to warm up to room temperature for $1 \mathrm{~h}$. The reaction mixture was quenched with an aqueous saturated solution of $\mathrm{NaHCO}_{3}$, the layers were separated and the aqueous phase was extracted with $\mathrm{Et}_{2} \mathrm{O}$. The combined organic layers were dried over anhydrous $\mathrm{Na}_{2} \mathrm{SO}_{4}$, filtered and concentrated under reduced pressure at room temperature. The resulting crude oil was then purified by flash column chromatography (light petroleum- $\mathrm{Et}_{2} \mathrm{O}, 9 / 1$ ) to yield the pure $23(10 \mathrm{mg}, 99 \%)$ as a $3: 1$ separable mixture of diastereomers. Major diastereomer $(11 R)-23:[\alpha]_{\mathrm{D}}^{36}-23.0,(c$ 1.0, $\left.\mathrm{CHCl}_{3}\right) ;{ }^{1} \mathrm{H}$ NMR (300 MHz, $\left.\mathrm{C}_{6} \mathrm{D}_{6}\right) \delta 0.07\left(6 \mathrm{H}, \mathrm{s}, 2 \times \mathrm{CH}_{3}\right), 0.79$ $\left(3 \mathrm{H}, \mathrm{d}, J=6.9 \mathrm{~Hz}, \mathrm{CH}_{3}\right), 0.87\left(3 \mathrm{H}, \mathrm{d}, J=6.7 \mathrm{~Hz}, \mathrm{CH}_{3}\right), 0.98(9 \mathrm{H}$, $\left.\mathrm{s}, 3 \times \mathrm{CH}_{3}\right), 1.19-1.45\left(5 \mathrm{H}, \mathrm{m}, 2 \times \mathrm{CH}_{2}\right.$ and $\left.\mathrm{OH}\right), 1.51-1.61(1 \mathrm{H}$, $\mathrm{m}, \mathrm{CH}), 2.12-2.24(1 \mathrm{H}, \mathrm{m}, \mathrm{CH}), 2.17\left(3 \mathrm{H}, \mathrm{d}, J=1.3 \mathrm{~Hz}, \mathrm{CH}_{3}\right)$, 3.05-3.11 (1H, m, CH), 3.33-3.42 (1H, m, CH $\left.H_{2}\right), 6.16(1 \mathrm{H}, \mathrm{br}$ $\mathrm{dq}, J=10.0$ and $1.3 \mathrm{~Hz}, \mathrm{CH}) ;{ }^{13} \mathrm{C}$ NMR $\left(75 \mathrm{MHz}, \mathrm{C}_{6} \mathrm{D}_{6}\right) \delta-5.1$ $\left(2 \times \mathrm{CH}_{3}\right), 16.8\left(\mathrm{CH}_{3}\right), 17.1\left(\mathrm{CH}_{3}\right), 18.6(\mathrm{C}), 26.3\left(3 \times \mathrm{CH}_{3}\right), 28.1$ $\left(\mathrm{CH}_{3}\right), 29.7\left(\mathrm{CH}_{2}\right), 32.4\left(\mathrm{CH}_{2}\right), 36.0(\mathrm{CH}), 41.9(\mathrm{CH}), 68.6\left(\mathrm{CH}_{2}\right)$, $74.9(\mathrm{CH}), 94.6(\mathrm{C}), 143.5(\mathrm{CH})$; IR (thin film) $\nu_{\max }=3397$, 2954, 2928, 2856, 1462, 1377, 1361, 1251, $1090 \mathrm{~cm}^{-1}$; LRMS $m / z$ (ESI) $449(\mathrm{M}+\mathrm{Na})^{+}$; HRMS $m / z$ (ESI) calcd for $\mathrm{C}_{17} \mathrm{H}_{36} \mathrm{O}_{2} \mathrm{SiI}$ $[\mathrm{M}+\mathrm{H}]^{+}:$427.1524, found 427.1523 .

Procedure C: To a stirred solution of ketone 22 (17 $\mathrm{mg}$, $0.04 \mathrm{mmol})$ in THF $(1 \mathrm{~mL})$ was added at $-55^{\circ} \mathrm{C}(R)$-CBS $(1.0 \mathrm{M}$ in THF, $79 \mu \mathrm{L}, 0.079 \mathrm{mmol}$ ) followed by $\mathrm{BH}_{3} \cdot \mathrm{THF}(1 \mathrm{M}$ in THF, $79 \mu \mathrm{L}, 0.079 \mathrm{mmol})$. The solution was stirred at $-55^{\circ} \mathrm{C}$ until completion ( $20 \mathrm{~min}$ ) and allowed to warm up to room temperature for $1 \mathrm{~h}$. The reaction mixture was quenched with an aqueous saturated solution of $\mathrm{NaHCO}_{3}$, the layers were separated and the aqueous phase was extracted with $\mathrm{Et}_{2} \mathrm{O}$. The combined organic layers were dried over anhydrous $\mathrm{Na}_{2} \mathrm{SO}_{4}$, filtered and concentrated under reduced pressure at room temperature. The resulting crude oil was then purified by flash column chromatography (light petroleum-Et ${ }_{2} \mathrm{O}, 9 / 1$ ) to yield the pure $23(12 \mathrm{mg}, 75 \%)$ as a $1: 6$ separable mixture of diastereomers. Major diastereomer $(11 S)-23$ : $[\alpha]_{\mathrm{D}}^{36}-31.8$, (c 1.0, $\left.\mathrm{CHCl}_{3}\right) ;{ }^{1} \mathrm{H}$ NMR $\left(300 \mathrm{MHz}, \mathrm{C}_{6} \mathrm{D}_{6}\right) \delta 0.07\left(6 \mathrm{H}, \mathrm{s}, 2 \times \mathrm{CH}_{3}\right), 0.84$ $\left(3 \mathrm{H}, \mathrm{d}, J=6.8 \mathrm{~Hz}, \mathrm{CH}_{3}\right), 0.89\left(3 \mathrm{H}, \mathrm{d}, J=6.4 \mathrm{~Hz}, \mathrm{CH}_{3}\right), 0.98(9 \mathrm{H}$, $\left.\mathrm{s}, 3 \times \mathrm{CH}_{3}\right), 0.99-1.06\left(1 \mathrm{H}, \mathrm{m}, \mathrm{CH}_{2}\right), 1.11-1.21\left(1 \mathrm{H}, \mathrm{m}, \mathrm{CH}_{2}\right)$,
$1.25(1 \mathrm{H}$, br s, OH $), 1.35-1.46\left(1 \mathrm{H}, \mathrm{m}, \mathrm{CH}_{2}\right), 1.48-1.60(2 \mathrm{H}, \mathrm{m}$, $\mathrm{CH}$ and $\left.\mathrm{CH}_{2}\right), 2.17\left(3 \mathrm{H}, \mathrm{d}, J=1.5 \mathrm{~Hz}, \mathrm{CH}_{3}\right), 2.19-2.27(1 \mathrm{H}, \mathrm{m}$, $\mathrm{CH}), 3.03-3.11(1 \mathrm{H}, \mathrm{m}, \mathrm{CH}), 3.34(1 \mathrm{H}, \mathrm{dd}, J=9.8$ and $5.6 \mathrm{~Hz}$, $\left.\mathrm{CH}_{2}\right), 3.41\left(1 \mathrm{H}, \mathrm{dd}, J=9.8\right.$ and $\left.5.6 \mathrm{~Hz}, \mathrm{CH}_{2}\right), 6.08(1 \mathrm{H}, \mathrm{dq}, J=$ 10.0 and $1.5 \mathrm{~Hz}, \mathrm{CH}) ;{ }^{13} \mathrm{C} \mathrm{NMR}\left(75 \mathrm{MHz}, \mathrm{C}_{6} \mathrm{D}_{6}\right) \delta-5.1(2 \times$ $\left.\mathrm{CH}_{3}\right), 15.5\left(\mathrm{CH}_{3}\right), 17.3\left(\mathrm{CH}_{3}\right), 18.6(\mathrm{C}), 26.3\left(3 \times \mathrm{CH}_{3}\right), 28.0$ $\left(\mathrm{CH}_{3}\right), 29.8\left(\mathrm{CH}_{2}\right), 32.4\left(\mathrm{CH}_{2}\right), 36.1(\mathrm{CH}), 42.0(\mathrm{CH}), 68.3\left(\mathrm{CH}_{2}\right)$, $75.2(\mathrm{CH}), 94.1(\mathrm{C}), 144.5(\mathrm{CH})$; IR (thin film) $\nu_{\max }=3358$, 2954, 2928, 2856, 1633, 1462, 1378, 1361, 1252, $1092 \mathrm{~cm}^{-1}$; LRMS $\mathrm{m} / \mathrm{z}$ (ESI) $449(\mathrm{M}+\mathrm{Na})^{+}$; HRMS $\mathrm{m} / \mathrm{z}$ (ESI) calcd for $\mathrm{C}_{17} \mathrm{H}_{36} \mathrm{O}_{2} \mathrm{SiI}[\mathrm{M}+\mathrm{H}]^{+}:$427.1524, found 427.1521.

Compound 7. A solution of alcohol $23(235 \mathrm{mg}, 0.55 \mathrm{mmol})$ in anhydrous dichloromethane $(5 \mathrm{~mL})$ was cooled down to $-78{ }^{\circ} \mathrm{C}$ and treated with 2,6-lutidine $(146 \mu \mathrm{L}, 1.26 \mathrm{mmol})$ followed by tert-butyldimethylsilyl trifluoromethanesulfonate (146 $\mu \mathrm{l}, 0.64 \mathrm{mmol})$. Completion was achieved within $10 \mathrm{~min}$ at $-78{ }^{\circ} \mathrm{C}$ as indicated by TLC analysis and the reaction mixture was quenched by addition of a saturated solution of $\mathrm{NH}_{4} \mathrm{Cl}(5 \mathrm{~mL})$. The reaction mixture was transferred to a separating funnel containing diethyl ether and the organics were washed with water. After drying over anhydrous $\mathrm{Na}_{2} \mathrm{SO}_{4}$, and subsequent filtration, the solvents were evaporated under reduced pressure. The resulting crude oil was purified by flash column chromatography (100\% light petroleum) to give the pure bis-TBS protected diol 7 (297 $\mathrm{mg}, 99 \%)$ as a clear colourless oil. $[\alpha]_{\mathrm{D}}^{25}-33.3,\left(c 1.0, \mathrm{CHCl}_{3}\right) ;{ }^{1} \mathrm{H} \mathrm{NMR}\left(300 \mathrm{MHz}, \mathrm{C}_{6} \mathrm{D}_{6}\right) \delta$ $0.07\left(6 \mathrm{H}, \mathrm{s}, 2 \times \mathrm{CH}_{3}\right), 0.08\left(6 \mathrm{H}, \mathrm{s}, 2 \times \mathrm{CH}_{3}\right), 0.85(3 \mathrm{H}, \mathrm{d}, J=6.8$ $\left.\mathrm{Hz}, \mathrm{CH}_{3}\right), 0.90\left(3 \mathrm{H}, \mathrm{d}, J=6.5 \mathrm{~Hz}, \mathrm{CH}_{3}\right), 0.98\left(9 \mathrm{H}, \mathrm{s}, 3 \times \mathrm{CH}_{3}\right)$, $1.00\left(9 \mathrm{H}, \mathrm{s}, 3 \times \mathrm{CH}_{3}\right), 1.10-1.20\left(1 \mathrm{H}, \mathrm{m}, \mathrm{CH}_{2}\right), 1.33-1.61(4 \mathrm{H}$, $\mathrm{m}, \mathrm{CH}_{2}$ and $\mathrm{CH}_{2}$ and $\left.\mathrm{CH}\right), 2.24\left(3 \mathrm{H}, \mathrm{d}, J=1.5 \mathrm{~Hz}, \mathrm{CH}_{3}\right)$, 2.37-2.49 (1H, m, CH), 3.35-3.45 (3H, m, CH and $\left.\mathrm{CH}_{2}\right), 6.24$ $(1 \mathrm{H}, \mathrm{dq}, J=10.0$ and $1.4 \mathrm{~Hz}, \mathrm{CH}) ;{ }^{13} \mathrm{C} \mathrm{NMR}\left(100 \mathrm{MHz}, \mathrm{C}_{6} \mathrm{D}_{6}\right) \delta$ $-5.2\left(2 \times \mathrm{CH}_{3}\right),-4.1\left(\mathrm{CH}_{3}\right),-4.0\left(\mathrm{CH}_{3}\right), 16.4\left(\mathrm{CH}_{3}\right), 16.9\left(\mathrm{CH}_{3}\right)$, $18.3(\mathrm{C}), 18.6\left(\mathrm{CH}_{3}\right), 26.2\left(3 \times \mathrm{CH}_{3}\right), 26.2\left(3 \times \mathrm{CH}_{3}\right), 28.0\left(\mathrm{CH}_{3}\right)$, $28.7\left(\mathrm{CH}_{2}\right), 32.1\left(\mathrm{CH}_{2}\right), 36.4(\mathrm{CH}), 40.8(\mathrm{CH}), 68.5\left(\mathrm{CH}_{2}\right), 75.9$ (CH), 94.1 (C), $144.3(\mathrm{CH})$; LRMS m/z (ESI) $563(\mathrm{M}+\mathrm{Na})^{+}$; HRMS $m / z$ (ESI) calcd for $\mathrm{C}_{23} \mathrm{H}_{53} \mathrm{NO}_{2} \mathrm{Si}_{2} \mathrm{I}\left[\mathrm{M}+\mathrm{NH}_{4}\right]^{+}: 558.2654$, found 558.2651.

Compound 24. Bis-TBS protected diol 7 (260 mg, $0.48 \mathrm{mmol}$ ) was diluted in a 1:1 mixture of regular dichloromethane and methanol $(3.2 \mathrm{~mL})$ in a round bottom flask open to the air. The solution was cooled down to $0{ }^{\circ} \mathrm{C}$ and was treated with 10-camphorsulfonic acid (27 $\mathrm{mg}, 0.12 \mathrm{mmol}$ ). The reaction mixture was stirred at $0{ }^{\circ} \mathrm{C}$ until complete disappearance of the starting material as indicated by TLC (45 min) and was then quenched by addition of solid sodium bicarbonate (90 $\mathrm{mg}, \mathrm{mmol})$ at $0{ }^{\circ} \mathrm{C}$. After stirring the suspension for $10 \mathrm{~min}$ at $0{ }^{\circ} \mathrm{C}$, then $10 \mathrm{~min}$ at room temperature, it was filtered through a piece of cotton wool and concentrated. The residue was diluted with diethyl ether $(5 \mathrm{~mL})$ and filtered through Celite ${ }^{\circledR}$. Concentration under reduced pressure gave a clear yellowish crude oil which was purified by flash column chromatography (light petroleum-Et ${ }_{2} \mathrm{O}, 9 / 1$ to $1 / 1$ ) to yield the pure alcohol $24(205 \mathrm{mg}, 99 \%)$ as a clear and colourless oil. $[\alpha]_{\mathrm{D}}^{25}-32.8,\left(c\right.$ 1.0, $\left.\mathrm{CHCl}_{3}\right) ;{ }^{1} \mathrm{H}$ NMR $\left(400 \mathrm{MHz}, \mathrm{C}_{6} \mathrm{D}_{6}\right) \delta 0.05$ $\left(3 \mathrm{H}, \mathrm{s}, \mathrm{CH}_{3}\right), 0.06\left(3 \mathrm{H}, \mathrm{s}, \mathrm{CH}_{3}\right), 0.83(2 \times 3 \mathrm{H}, 2 \times \mathrm{d}$ overlapped, 
$\left.J=6.7 \mathrm{~Hz}, 2 \times \mathrm{CH}_{3}\right), 0.97\left(9 \mathrm{H}, \mathrm{s}, 3 \times \mathrm{CH}_{3}\right), 1.01-1.06(1 \mathrm{H}, \mathrm{m}$, $\left.\mathrm{CH}_{2}\right), 1.29-1.49\left(4 \mathrm{H}, \mathrm{m}, \mathrm{CH}_{2}\right.$ and $\mathrm{CH}_{2}$ and $\left.\mathrm{CH}\right), 2.22(3 \mathrm{H}, \mathrm{d}, J=$ $\left.1.5 \mathrm{~Hz}, \mathrm{CH}_{3}\right), 2.35-2.44(1 \mathrm{H}, \mathrm{m}, \mathrm{CH}), 3.17$ (1H, dd, $J=10.0$ and $\left.6.0 \mathrm{~Hz}, \mathrm{CH}_{2}\right), 3.23\left(1 \mathrm{H}, \mathrm{dd}, J=10.3\right.$ and $\left.5.5 \mathrm{~Hz}, \mathrm{CH}_{2}\right), 3.33(1 \mathrm{H}$, q, $J=5.0 \mathrm{~Hz}, \mathrm{CH}), 6.23(1 \mathrm{H}, \mathrm{br} \mathrm{dq}, J=10.0$ and $1.5 \mathrm{~Hz}, \mathrm{CH})$; ${ }^{13} \mathrm{C}$ NMR $\left(75 \mathrm{MHz}, \mathrm{C}_{6} \mathrm{D}_{6}\right) \delta-4.2\left(\mathrm{CH}_{3}\right),-4.1\left(\mathrm{CH}_{3}\right), 16.5\left(\mathrm{CH}_{3}\right)$, $16.8\left(\mathrm{CH}_{3}\right), 18.3(\mathrm{C}), 26.2\left(3 \times \mathrm{CH}_{3}\right), 28.0\left(\mathrm{CH}_{3}\right), 28.6\left(\mathrm{CH}_{2}\right), 32.2$ $\left(\mathrm{CH}_{2}\right), 36.2(\mathrm{CH}), 40.7(\mathrm{CH}), 67.9\left(\mathrm{CH}_{2}\right), 75.8(\mathrm{CH}), 94.1(\mathrm{C})$, $144.2(\mathrm{CH})$; LRMS $m / z$ (ESI) $449(\mathrm{M}+\mathrm{Na})^{+}$; HRMS $\mathrm{m} / z$ (ESI) calcd for $\mathrm{C}_{17} \mathrm{H}_{36} \mathrm{O}_{2} \mathrm{SiI}[\mathrm{M}+\mathrm{H}]^{+}$: 427.1524, found 427.1517.

Compound 25. A solution of alcohol 24 (200 $\mathrm{mg}$, $0.47 \mathrm{mmol})$ in dichloromethane $(12 \mathrm{~mL})$ was cooled down to $0{ }^{\circ} \mathrm{C}$ and treated with Dess-Martin periodinane $(440 \mathrm{mg}$, $1.04 \mathrm{mmol}$ ). The reaction mixture was allowed to warm up slowly and was stirred at room temperature until completion (30 $\mathrm{min}$ ) as indicated by TLC analysis. The reaction mixture was quenched at $0{ }^{\circ} \mathrm{C}$ by addition of a $1: 1$ mixture of saturated aqueous solutions of $\mathrm{Na}_{2} \mathrm{~S}_{2} \mathrm{O}_{3}$ and $\mathrm{NaHCO}_{3}(44 \mathrm{~mL})$. The biphasic mixture was stirred at $0{ }^{\circ} \mathrm{C}$ until both phases become clear and was then transferred to a separating funnel containing diethyl ether. The phases were separated and the organic layer was washed with $\mathrm{Na}_{2} \mathrm{~S}_{2} \mathrm{O}_{3}, \mathrm{NaHCO}_{3}$ and then with water. The organic fraction was subsequently dried over anhydrous $\mathrm{Na}_{2} \mathrm{SO}_{4}$, filtered and concentrated under reduced pressure at room temperature. The resulting clear and colourless crude oil was then purified by flash column chromatography (light petroleum-Et ${ }_{2} \mathrm{O}, 99 / 1$ to $9 / 1$ ) to yield the pure sensitive aldehyde $25(170 \mathrm{mg}, 85 \%)$ as a clear and colourless oil. $[\alpha]_{\mathrm{D}}^{28}-46.0$, (c 1.0, $\left.\mathrm{CHCl}_{3}\right) ;{ }^{1} \mathrm{H}$ NMR (300 MHz, $\left.\mathrm{C}_{6} \mathrm{D}_{6}\right) \delta 0.00\left(3 \mathrm{H}, \mathrm{s}, \mathrm{CH}_{3}\right)$, $0.03\left(3 \mathrm{H}, \mathrm{s}, \mathrm{CH}_{3}\right), 0.77\left(3 \mathrm{H}, \mathrm{d}, J=6.9 \mathrm{~Hz}, \mathrm{CH}_{3}\right), 0.78(3 \mathrm{H}, \mathrm{d}, J=$ $\left.7.1 \mathrm{~Hz}, \mathrm{CH}_{3}\right), 0.94\left(9 \mathrm{H}, \mathrm{s}, 3 \times \mathrm{CH}_{3}\right), 1.07-1.16\left(1 \mathrm{H}, \mathrm{m}, \mathrm{CH}_{2}\right)$, 1.18-1.32 (2H, m, CH $)$, 1.41-1.56 (1H, m, CH $\left.\mathrm{C}_{2}\right), 1.73-1.84(1 \mathrm{H}$, m, CH), $2.20\left(3 \mathrm{H}, \mathrm{d}, J=1.5 \mathrm{~Hz}, \mathrm{CH}_{3}\right), 2.24-2.41(1 \mathrm{H}, \mathrm{m}, \mathrm{CH})$, $3.26(1 \mathrm{H}, \mathrm{q}, J=5.5 \mathrm{~Hz}, \mathrm{CH}), 6.14(1 \mathrm{H}, \mathrm{br} \mathrm{dq}, J=10.0$ and $1.5 \mathrm{~Hz}, \mathrm{CH}), 9.30(1 \mathrm{H}, \mathrm{d}, J=1.3 \mathrm{~Hz}, \mathrm{CH}) ;{ }^{13} \mathrm{C} \mathrm{NMR}(75 \mathrm{MHz}$, $\left.\mathrm{C}_{6} \mathrm{D}_{6}\right) \delta-4.2\left(\mathrm{CH}_{3}\right),-4.1\left(\mathrm{CH}_{3}\right), 13.3\left(\mathrm{CH}_{3}\right), 16.2\left(\mathrm{CH}_{3}\right), 18.3$ $\left(\mathrm{CH}_{3}\right), 25.8\left(\mathrm{CH}_{2}\right), 26.1\left(3 \times \mathrm{CH}_{3}\right), 27.9\left(\mathrm{CH}_{3}\right), 31.6\left(\mathrm{CH}_{2}\right), 40.8$ $(\mathrm{CH}), 46.2(\mathrm{CH}), 75.2(\mathrm{CH}), 94.3(\mathrm{C}), 144.0(\mathrm{CH}), 202.9(\mathrm{CH})$; IR (thin film) $\nu_{\max }=2256,2931,2858,1709,1472,1464,1379$, 1361, 1254, 1067, 1045, 1027, $1006 \mathrm{~cm}^{-1}$; LRMS m/z (ESI) 447 $(\mathrm{M}+\mathrm{Na})^{+}$.

Compound 26. A solution of pure aldehyde 25 (160 mg, $0.377 \mathrm{mmol}$ ) in anhydrous diethyl ether $(2.4 \mathrm{~mL})$ was cooled down to $-78{ }^{\circ} \mathrm{C}$ and treated with methylmagnesium bromide (3.0 $\mathrm{M}$ in diethyl ether, $310 \mu \mathrm{L}, 0.93 \mathrm{mmol}$ ). Completion was achieved within $15 \mathrm{~min}$ as indicated by TLC analysis and the reaction mixture was then quenched by addition of a saturated solution of $\mathrm{NH}_{4} \mathrm{Cl}(2.4 \mathrm{~mL})$ at $-78^{\circ} \mathrm{C}$. The mixture was allowed to stir at room temperature for $10 \mathrm{~min}$ and was then transferred to a separating funnel. The phases were separated and the ethereal layer was dried over anhydrous $\mathrm{Na}_{2} \mathrm{SO}_{4}$. Concentration under reduced pressure gave the crude secondary alcohol 26. Purification by flash column chromatography (light petroleum- $\mathrm{Et}_{2} \mathrm{O}, 9 / 1$ ) provided the pure alcohol 26 (152 $\mathrm{mg}, 92 \%)$ as a clear and colourless oil and as a $1: 1.5$ mixture of unseparable diastereoisomers. The alcohol is not described because the mixture of diastereomers. IR (thin film) $\nu_{\max }=3364,2957,2928,2883,2857,1471,1461,1406$, 1378, 1361, 1253, 1065, 1027, 1004, $942 \mathrm{~cm}^{-1}$; LRMS m/z (ESI) $463(\mathrm{M}+\mathrm{Na})^{+}$; HRMS $m / z($ ESI $)$ calcd for $\mathrm{C}_{18} \mathrm{H}_{38} \mathrm{O}_{2} \mathrm{SiI}[\mathrm{M}+\mathrm{H}]^{+}$: 441.1680, found 441.1667 .

Compound 6. A solution of alcohol $26(140 \mathrm{mg}, 0.32 \mathrm{mmol})$ in dichloromethane $(7 \mathrm{~mL})$ was cooled down to $0{ }^{\circ} \mathrm{C}$ and treated with the DMP reagent (365 $\mathrm{mg}, 0.86 \mathrm{mmol}$ ). After $10 \mathrm{~min}$ at $0{ }^{\circ} \mathrm{C}$, the reaction mixture was allowed to warm up slowly and was stirred at room temperature until completion (45 $\mathrm{min}$ ) as indicated by TLC analysis. The reaction mixture was quenched at $0{ }^{\circ} \mathrm{C}$ by addition of a $1: 1$ mixture of saturated aqueous solutions of $\mathrm{Na}_{2} \mathrm{~S}_{2} \mathrm{O}_{3}$ and $\mathrm{NaHCO}_{3}(40 \mathrm{~mL})$. The biphasic mixture was stirred at $0{ }^{\circ} \mathrm{C}$ until both phases become clear and was then transferred to a separating funnel containing diethyl ether. The phases were separated and the organic layer was washed with the $\mathrm{Na}_{2} \mathrm{~S}_{2} \mathrm{O}_{3}, \mathrm{NaHCO}_{3}$ and then with water. The organic fraction was subsequently dried over anhydrous $\mathrm{Na}_{2} \mathrm{SO}_{4}$, filtered and concentrated under reduced pressure at room temperature. The resulting clear yellowish crude oil was then purified by flash column chromatography (light petroleum- $\mathrm{Et}_{2} \mathrm{O}, 99 / 1$ to $9 / 1$ ) to yield the pure ketone 6 (126 mg, 91\%) as a clear and colourless oil. $[\alpha]_{\mathrm{D}}^{36}-28.6$, (c 1.0, $\left.\mathrm{CHCl}_{3}\right) ;{ }^{1} \mathrm{H}$ NMR (300 MHz, $\left.\mathrm{C}_{6} \mathrm{D}_{6}\right) \delta 0.03\left(3 \mathrm{H}, \mathrm{s}, \mathrm{CH}_{3}\right), 0.04$ $\left(3 \mathrm{H}, \mathrm{s}, \mathrm{CH}_{3}\right), 0.79\left(3 \mathrm{H}, \mathrm{d}, J=6.8 \mathrm{~Hz}, \mathrm{CH}_{3}\right), 0.87(3 \mathrm{H}, \mathrm{d}, J=7.0$ $\left.\mathrm{Hz}, \mathrm{CH}_{3}\right), 0.95\left(9 \mathrm{H}, \mathrm{s}, 3 \times \mathrm{CH}_{3}\right), 1.15-1.38\left(3 \mathrm{H}, \mathrm{m}, \mathrm{CH}_{2}\right.$ and $\left.\mathrm{CH}_{2}\right), 1.49-1.59\left(1 \mathrm{H}, \mathrm{m}, \mathrm{CH}_{2}\right), 1.75\left(3 \mathrm{H}, \mathrm{s}, \mathrm{CH}_{3}\right), 2.01-2.10(1 \mathrm{H}$, $\mathrm{m}, \mathrm{CH}), 2.21\left(3 \mathrm{H}, \mathrm{d}, J=1.5 \mathrm{~Hz}, \mathrm{CH}_{3}\right), 2.28-2.40(1 \mathrm{H}, \mathrm{m}, \mathrm{CH})$, 3.26-3.31 (1H, m, CH), $6.17(1 \mathrm{H}, \mathrm{br} \mathrm{dq}, J=10.0$ and $1.5 \mathrm{~Hz}$, $\mathrm{CH}) ;{ }^{13} \mathrm{C}$ NMR $\left(75 \mathrm{MHz}, \mathrm{C}_{6} \mathrm{D}_{6}\right) \delta-4.2\left(\mathrm{CH}_{3}\right),-4.1\left(\mathrm{CH}_{3}\right), 16.3$ $\left(\mathrm{CH}_{3}\right), 16.5\left(\mathrm{CH}_{3}\right), 18.3(\mathrm{C}), 26.2\left(3 \times \mathrm{CH}_{3}\right), 27.8\left(\mathrm{CH}_{3}\right), 28.0$ $\left(\mathrm{CH}_{3}\right), 28.3\left(\mathrm{CH}_{2}\right), 32.3\left(\mathrm{CH}_{2}\right), 40.7(\mathrm{CH}), 47.0(\mathrm{CH}), 75.4(\mathrm{CH})$, $94.3(\mathrm{CH}), 144.0(\mathrm{CH}), 209.6(\mathrm{CH})$; IR (thin film) $\nu_{\max }=2955$, 2929, 2856, 1713, 1471, 1461, 1378, 1359, 1253, 1170, 1067, 1043, 1026, 1006, $940 \mathrm{~cm}^{-1}$; LRMS m/z (ESI) $461(\mathrm{M}+\mathrm{Na})^{+}$; HRMS $m / z$ (ESI) calcd for $\mathrm{C}_{18} \mathrm{H}_{36} \mathrm{O}_{2} \mathrm{SiI}[\mathrm{M}+\mathrm{H}]^{+}:$439.1524, found 439.1517 .

\section{Acknowledgements}

Aix-Marseille Université is gratefully acknowledged for financial support for S.M. J.-F. Betzer is also acknowledged for fruitful discussion.

\section{Notes and references}

1 (a) F. J. Schmitz, S. P. Gunasekera, G. Yalamanchili, M. B. Hossain and D. van der Helm, J. Am. Chem. Soc., 1984, 106, 7251; (b) N. Fusetani, T. Sugawara, S. Matsunaga and H. Hirota, J. Org. Chem., 1991, 56, 4971; (c) C. Chevallier, T. S. Bugni, X. Feng, M. K. Harper, A. M. Orendt and C. M. Ireland, J. Org. Chem., 2006, 71, 2510. 
2 (a) T. L. Meragelman, R. H. Willis, G. M. Woldemichael, A. Heaton, P. T. Murphy, K. M. Snader, D. J. Newman, R. Van Soest, M. R. Boyd, J. H. Cardellina and T. C. McKee, J. Nat. Prod., 2007, 70, 1133; (b) E. L. Whitson, K. M. Pluchino, M. D. Hall, J. B. McMahon and T. C. McKee, Org. Lett., 2011, 13, 3518.

3 F. J. Schmitz, S. P. Gunasekera, M. B. Hossain, D. van der Helm and G. Yalamanchili, U.S. Pat. Appl., 1988, 87, 7347.

4 (a) S. Nishimura, S. Matsunaga, M. Yoshida, H. Hirota, S. Yokoyama and N. Fusetani, Bioorg. Med. Chem., 2005, 13, 449; (b) S. Nishimura, S. Matsunaga, S. Yoshida, Y. Nakao, H. Hirota and N. Fusetani, Bioorg. Med. Chem., 2005, 13, 455; (c) S. J. Schroeder, G. Blaha, J. Tirado-Rives, T. A. Steitz and P. B. Moore, Mol. Biol., 2007, 367, 1471.

5 Total synthesis of 1 and 2. (a) A. B. Smith III, C. M. Adams, S. A. Lodise Barbosa and A. P. Degnan, J. Am. Chem. Soc., 2003, 125, 350; (b) A. B. Smith III and D. Lee, J. Am. Chem. Soc., 2007, 129, 10957; (c) L. D. Julian, J. S. Newcom and W. R. Roush, J. Am. Chem. Soc., 2005, 127, 6186; (d) G. Ehrlich, J. Hassfeld, U. Eggert and M. Kalesse, J. Am. Chem. Soc., 2006, 128, 14038; (e) N. Diaz, M. Zhu, G. Ehrlich, U. Eggert, Y. Muthukumar, F. Sasse and M. Kalesse, Chem.-Eur. J., 2012, 18, 4946. For a review: M. Roy and M. Kalesse, Nat. Prod. Rep., 2008, 25, 862.

6 (a) E. de Lemos, F.-H. Porée, A. Bourin, J. Barbion, E. Agouridas, M.-I. Lannou, A. Commerçon, J.-F. Betzer, A. Pancrazi and J. Ardisson, Chem.-Eur. J., 2008, 14, 11092; (b) E. de Lemos, F.-H. Porée, A. Commerçon, J.-F. Betzer, A. Pancrazi and J. Ardisson, Angew. Chem., Int. Ed., 2007, 46, 1917.
7 (a) J. Chan and T. F. Jamison, J. Am. Chem. Soc., 2003, 125, 11514; (b) J. Chan and T. F. Jamison, J. Am. Chem. Soc., 2004, 126, 10682.

8 (a) J. R. Gage and D. A. Evans, Org. Synth., 1990, 68, 83; (b) J. R. Gage and D. A. Evans, Org. Synth., 1990, 68, 77.

9 D. B. Hansen, M.-L. Starr, N. Tolstoy and M. M. Joullié, Tetrahedron: Asymmetry, 2005, 16, 3623.

10 C. Lentsch and U. Rinner, Org. Lett., 2009, 11, 5326.

11 C. Botteghi, G. Consiglio, G. Ceccarelli and A. Stefani, J. Org. Chem., 1972, 37, 1835.

12 (a) T. Fujisawa, Y. Kurita, M. Kawashima and T. Sato, Chem. Lett., 1982, 1641; (b) P. Kocienski, S. Wadman and K. Cooper, J. Am. Chem. Soc., 1989, 111, 2363; (c) P. Kocienski and C. Barber, Pure Appl. Chem., 1990, 62, 1933; (d) P. Kocienski, in Organic Synthesis via Organometallics (OSM 4, Aachen), ed. E. Enders, H.-J. Gais and W. Keim, Vieweg, Wiesbaden, Germany, 1993, pp. 203-223; (e) V. Fargeas, P. Le Ménez, I. Berque, J. Ardisson and A. Pancrazi, Tetrahedron, 1996, 52, 6613; $(f)$ P. Le Menez, J.-D. Brion, J.-F. Betzer, A. Pancrazi and J. Ardisson, Synlett, 2003, 955.

13 P. Baekelmans, M. Gielen, P. Malfroid and J. Nasielski, Bull. Soc. Chim. Belg., 1968, 77, 85.

14 L. A. Paquette, R. Guevel, S. Sakamoto, I. H. Kim and J. Crawford, J. Org. Chem., 2003, 68, 6096.

15 D. B. Dess and J. C. Martin, J. Am. Chem. Soc., 1991, 113, 7277.

16 E. J. Corey, R. K. Bakashi, S. Shibata, C. P. Chen and V. K. Singh, J. Am. Chem. Soc., 1987, 109, 7925. 